Article

\title{
International Human Trafficking: Measuring Clandestinity by the Structural Equation Approach
}

\author{
Alexandra Rudolph ${ }^{1, *}$ and Friedrich Schneider ${ }^{2}$ \\ ${ }^{1}$ German Development Institute/Deutsches Institut für Entwicklungspolitik (DIE), 53113 Bonn, Germany; \\ E-Mail: alexandra.rudolph@die-gdi.de \\ 2 Department of Economics, Johannes Kepler University of Linz, 4040 Linz, Austria; E-Mail: friedrich.schneider@jku.at \\ * Corresponding author
}

Submitted: 7 February 2017 | Accepted: 26 April 2017 | Published: 23 June 2017

\begin{abstract}
Worldwide human trafficking is the third most often registered international criminal activity, ranked only after drug and weapon trafficking. This article focusses on three questions: 1) How can human trafficking be measured? 2) What are the causes and indicators of this criminal activity which exploits individuals? 3) Which countries observe a high (or low) level of human trafficking inflow? We apply the Multiple Indicators Multiple Causes structural equation model to measure human trafficking inflows in a way which includes all potential causes and indicators in one estimation model. The human trafficking measurement focusses on international human trafficking. We use freely available existing data and thus generate an objective measure of the extent of trafficking. Countries are ranked according to their potential to be a destination country based on various characteristics of the trafficking process.
\end{abstract}

\section{Keywords}

human trafficking; international crime; latent variable; measurement; Multiple Indicators and Multiple Causes model; structural equation model

\section{Issue}

This article is part of the issue "Perspectives on Human Trafficking and Modern Forms of Slavery", edited by Siddharth Kara (Harvard Kennedy School, USA).

(C) 2017 by the authors; licensee Cogitatio (Lisbon, Portugal). This article is licensed under a Creative Commons Attribution 4.0 International License (CC BY).

\section{Introduction}

Since human trafficking is the third largest kind of illicit international commerce, after illegal drug and weapon smuggling (U.S. Department of State, 2004), it creates an underground economy of illegal labor markets and businesses where immense profits and great suffering go hand in hand. Profit estimates range from 1 billion dollars (Belser, 2005) to 31.61 billion dollars at any given time (ILO, 2005; Interpol, 2012). This money is augmented by tax evasion and presumably used to finance the illegal businesses that traffic individuals, as well as other associated activities. The trafficked are abused through exploitation and coercion and deprived of the freedom to move or choose their place of living (Gallagher, 2009). Like other transnational criminal activities, it links with the corruption of civil society as it bypasses borders, undermines state sovereignty, and threatens state governance and human security (Shelley, 1999).

The international nature of this crime means that an international response is needed in order to address policy approaches and legal measures successfully, particularly due to the fact that the main problem in this field is the availability of comparable data. A comparable international measure of trafficking intensity is currently still missing. This article provides a first attempt at providing the literature with a new means of measuring human trafficking by using the structural equation approach. ${ }^{1}$

\footnotetext{
${ }^{1}$ Several attempts have been carried out in order to increase data access in the "Trafficking Statistics Project": the United Nations Educational, Scientific and Cultural Organization (UNESCO) and the International Labor Organization (ILO) built the Counter-Trafficking Module (CTM) Database; the United
} 
The Multiple Indicators Multiple Causes (MIMIC) model is a special case of the structural equation model which uses existing data to derive a measurement of the extent of human trafficking. Thereby an index of human trafficking "based on estimated parameters that relate directly to the causes and indicators" (Dreher, Kotsogiannis, \& McCorriston, 2007, p. 445) can be drawn up. This approach has been used in economics by several authors to explore latent phenomena such as the shadow economy (Schneider \& Enste 2000, 2002) or corruption (Dreher et al., 2007).

In this article we understand human trafficking in accordance with the international definition of trafficking in persons. ${ }^{2}$ This source is not only the first successful international agreement on the common elements and implications of human trafficking, but it also provides an important working basis for the present research. ${ }^{3}$ The main elements are the inclusion of all forms of enslavement and the focus on the exploitation of victims through coercion or deception. They acknowledge that most of the victims of human trafficking are made vulnerable by migration, are not willingly enslaved, and that it is a clandestine business of internationally active criminal networks. To render the clandestine phenomenon of human trafficking visible, the objective of this article is to measure human trafficking by addressing the extent of victim exploitation in destination countries based on observed causes and indicators through the MIMIC structural equation approach. This allows us to explore the structural relationship between the causes and indicators of human trafficking, which to the best of our knowledge has not been investigated before.

In order to describe human trafficking as precisely as possible, aspects of both indicators and causes must be included, particularly since these have been neglected by earlier studies, which used multivariate approaches and focussed on factors that may cause human trafficking (e.g. Cho, 2015). The main idea behind the MIMIC model is to examine the relationship between an unobservable variable, e.g. the shadow economy, corruption, human trafficking, etc., and a set of observable variables (causes and indicators) using covariance information (Buehn \& Schneider, 2012). ${ }^{4}$ The flexibility in estimating the correlations of observable factors is one of the main advantages of the MIMIC approach. We disentangle these relationships and derive an index of the extent of trafficking in persons to destination countries by applying this single latent variable structural equation method. This method provides a detailed analysis of human trafficking, which sheds further light on the mechanism behind the trafficking process.

To summarize in advance the essential findings, the MIMIC estimates support the main assumptions as to the determinants and indicators of trafficking in persons. That is, specifically, that richer countries, investment relations, and opportunities for low-skilled labor positively correlate with human trafficking whereas language differences are negatively correlated. Indications of human trafficking inflows are the crime rate, legal measures against human trafficking, and the number of migrants registered in the countries. The human trafficking intensity index shows the prevalence of human trafficking to 142 destination countries for the period 2000-2010.

Section 2 explains the MIMIC model of human trafficking and presents the dynamics between indicators and causes of human trafficking. Thereafter, Section 3 discusses the results, the measurement of human trafficking, and country rankings. Section 4 concludes.

\section{The MIMIC Model of Human Trafficking}

In 1975, Jöreskog and Goldberger introduced the MIMIC model in economics. It has subsequently been used in numerous studies to measure unobservable variables such as the underground economy (e.g. Buehn \& Schneider, 2012, Frey \& Weck-Hanneman, 1984; Loayza, 1996; Schneider, Buehn, \& Montenegro, 2010), corruption (Dreher et al., 2007), and international goods smuggling (Buehn \& Farzanegan, 2012). ${ }^{5}$ Many studies further explored determining aspects and the development of underground activity across and within countries (among others Buehn, 2012; Loyaza, 1996).

There are several reasons for the application of the MIMIC model in the context of human trafficking. Firstly, human trafficking is an economically significant criminal activity with huge profits linked to tax evasion. Secondly, international human trafficking receives increased attention in the global policy arena and the international community is willing to fight it. This has already spurred an increase in studies analyzing the underlying processes in law, political science, and economics. However, international trafficking in human beings is a multidimensional, unobserved phenomenon in which the whole process happens in the underground economy and neither traffickers nor victims are easy to identify. A latent variable approach such as the MIMIC is thus well suited to ad-

Nations Office on Drugs and Crime (UNODC) initiated the program against Trafficking in Human Beings (GPAT); and the U.S. State Department publishes the yearly Trafficking in Persons reports comparing countries' legal responses towards human trafficking.

2 The definition is presented in the Palermo Protocol Article 3 (UN, 2000).

${ }^{3}$ Article 3 of the protocol states that "human trafficking is the recruitment, transportation, transfer, harboring or receipt of persons, by means of the threat or use of force or other forms of coercion, of abduction, of fraud, of deception, of the abuse of power or of a position of vulnerability or of the giving or receiving of payments or benefits to achieve the consent of a person having control over another person, for the purpose of exploitation. Exploitation shall include, at a minimum, the exploitation or the prostitution of others or other forms of sexual exploitation, forced labor or services, slavery or practices similar to slavery, servitude or the removal of organs" (United Nations, 2000).

${ }^{4}$ See Appendix for a detailed description of the MIMIC model and the generation of the factors score for the final index.

${ }^{5}$ Additionally, Di Tommaso, Raiser and Weeks (2007) and Kuklys (2004) analyzed institutional change in Eastern Europe and welfare measurement. Buehn and Eichler (2009) explored the connection between smuggling illegal and legal goods, and Buehn and Farzanegan (2013) developed an index of global air pollution. 
dress its unobservable nature. Through the simultaneous consideration of key determinants and indicators, light is shed on the presence and magnitude of human trafficking to a country. Thirdly, the ability to estimate the parameters of a single structural equation has greater value than estimating numerous regressions. The MIMIC approach is based on the assumption that causal factors of latent phenomena are not to be considered independently. Human trafficking is a process with many facets in which several factors shape the incentive structure of all the actors involved, i.e. traffickers, victims and governments. ${ }^{6}$

The application of the MIMIC model to human trafficking focusses on the extent of human trafficking in destination countries. ${ }^{7}$ We identify what drives people to exploit vulnerable individuals, i.e. the demand structure (pull factors), and what puts people in this vulnerable position, i.e. the potential supply (push factors). In economic terms, human trafficking is located in a market setting where supply and demand are met at the expense of vulnerable individuals. The main reason for the abuse and exploitation of people is global income disparity. Emigration is propelled by economic factors that drive people to migrate and take risks in order to find more prosperous living conditions. In particular, traffickers use their victims' vulnerability and bring them to countries where both the demand for cheap labor and exploitation profits are high. These are the key factors that help identify the indicators and causes of human trafficking to destination countries.

\subsection{Indicators}

The extent of human trafficking is not directly measurable so indicators have to be identified that are a function of human trafficking in destination countries. To the best of our knowledge we are the first to determine multiple indicators to measure its extent in destination countries. There are many aspects correlated with human trafficking that could partially indicate its prevalence in a country. After extensive research of anecdotal and governmental evidence (e.g. U.S. Department of State, 2010, $2011,2012,2013)$, it becomes apparent that human trafficking has a two-sided nature. Some consequences are visible, but its illegal nature requires most of the action to be covert. We identify four indicators of human trafficking that reflect the intensity of human trafficking in destination countries: (1) the crime rate per 100,000 people, (2) the 3P-index of anti-trafficking policies ${ }^{8}$, (3) the num- ber of identified human trafficking victims, and (4) the number of migrants registered in a country. In order to test the relationship between the indicators and human trafficking intensity $(\eta)$ the following measurement model is implemented:

$$
\left[\begin{array}{c}
\text { crime rate }_{i} \\
3 \text { P-index } \\
\text { victims }_{i} \\
\text { In migrants }
\end{array}\right]=\left[\beta_{1}, \beta_{2}, \beta_{3}\right] \times[\eta]+\left[\varepsilon_{1}, \varepsilon_{2}, \varepsilon_{3}\right]
$$

(Ad1): Awareness within countries plays an important role in the identification of human trafficking. Given that human trafficking is a large-scale illegal business, its infrastructure must be highly developed. The criminology literature supports this claim and stresses the link between the transport of illegal migrants, human trafficking, and organized crime throughout the entire process of deceiving, transporting, and exploiting people (Salt, 2000; Salt \& Stein, 1997; Schloenhardt, 2001). The extent of human trafficking in a country contributes to the overall prevalence of crime. Despite the hidden nature of the phenomenon, we are able to reveal it by looking at the occurrence of crime, measured as the level of crime in the country. We use the crime rate per 100,000 people taken from United Nations Surveys on Crime Trends and the Operations of Criminal Justice System (United Nations Office on Drugs and Crime [UNODC], 2008), which is the most complete set of cross-country crime data available.

(Ad2): The legal fight against crime is an indicator of the extent of human trafficking in the country. In order to explain this hypothesis, we look to the theory presented in the literature (e.g. Hathaway, 2007; Simmons, 2000) as to why states sign international treaties and enforce them domestically. This would suggest that countries which more rigorously prevent, suppress, and punish trafficking in persons are incentivized to do so because they have a higher intrinsic motivation for respecting human rights and expect the collateral consequences (such as international reputation and a strong civil society) to be more important than the costs of enforcement. The effect of enforcement on the incidence of violence, however, is not easily determined. In a meta-study which looked exclusively at the drug market, Werb et al. (2011) found that interference in the market for drugs leads to an increase in violent incidents. We apply this argument to the trafficking market and argue that where human trafficking is combated by stronger law enforce-

\footnotetext{
${ }^{6}$ Assumptions made about the effects of the latent variable have to be considered carefully. Cliff (1983, p. 120) argues that there might be relevant divergence between the observed indicators and the latent phenomenon. This is especially important when interpreting correlations and model estimates established from the latent variable specifications and relating them directly to the unobserved phenomenon. However it should be noted that this is not a major problem here because the model is tested on several different specifications and model applications, which show that the underlying assumptions seem to be valid. Nevertheless, estimation models are no more than approximations of the unknown real social phenomenon and have to be interpreted cautiously, especially when the core component being estimated (HT) is not observable.

7 Since October 2013, the Walk Free Foundation (2013) has measured the prevalence of people in slavery for 162 countries. This approach is based on risk characteristics of countries at one point in time. In contrast to the human trafficking intensity measure provided here, the measurement does not take into account development over time and is restricted to an analysis of the preceding year rather than of the last decade, and thus comparisons are difficult.

${ }^{8}$ A detailed description of the construction of the 3P-index is available in the article Cho et al. (2014) and online on the project webpage: www.humantrafficking-research.org
} 
ment in terms of prosecution, protection, and prevention, the more incidences of trafficking will be registered in the country. A measure of these anti-trafficking instruments is the 3P-index provided by Cho, Dreher and Neumayer (2014)..$^{9}$ It is available for over 180 countries for the 2001 to 2013 period. The higher the score a country receives in the 3P-index (on a scale of 3 to 15), the more rigorously the anti-trafficking instruments are implemented. Our argument is supported by the following observations: the Convention Against Transnational Crime and the Trafficking Protocol are the results of international observations "that technological advances, combined with the ever-growing inter-dependence of economies, is offering criminal groups unprecedented lucrative opportunities" (Betti, 2001, p. 1). During the negotiations and the implementation of the Convention Against Transnational Crime and the Trafficking Protocol, public awareness of the topic increased substantially. Non-governmental organizations intensified public awareness campaigns and media coverage of human trafficking as an international criminal activity became ubiquitous. ${ }^{10}$ The increased salience of the topic forced policy makers to react and intensify the fight against it (Burstein, 2003, and sources cited there). In a simple correlation test between the 3P-index and the number of identified victims, we find a positive and significant correlation. We therefore argue that the 3P-index is a good indicator of human trafficking in the country.

$\operatorname{Ad}(3)$ : The number of identified victims in these countries gives an indication of the true number of victims. Although it is important to note that identification of victims, prosecution of traffickers, and prevention of the crime largely depend on the awareness of the existence of human trafficking in the wider public, as well as in legal institutions (Tyldum \& Brunovskis, 2005), this number is an important sign of the existence of trafficking in persons. The indicator of the observed number of victims is a proxy for the total extent of the issue: it is only the tip of the iceberg. This observed number is affected by the quality of the law enforcement institutions in the destination country. Presumably the numbers are larger in countries with better institutions and therefore not necessarily where trafficking is more prevalent. However, the number of identified victims should be larger where the pool of all victims is larger, which suggests a positive correlation between the real extent and identified victims. In its global reports on trafficking in persons (UNODC, 2009,2012 ), the UNODC provides the number of identified victims as a share of the total population for a large set of countries. ${ }^{11}$
$\mathrm{Ad}(4)$ : Finally, as argued before, victim exploitation happens parallel to migration flows and we therefore use the number of migrants (in logs) as an indicator of human trafficking. The number of international migrants is available from the World Bank Development Indicators (World Bank, 2012). In order to obtain data for each year of the sample, we interpolate from the number of refugees as counted every five years by the Office of the United Nations High Commissioner for Human Rights.

\subsection{Causes}

The structural model includes not only all causes of human trafficking that influence the vulnerability of individuals and thereby pull them towards promising destination countries but also criminal aspects of the phenomenon. Since the application of the common definition of human trafficking in 2000, the number of studies on the causes of human trafficking has increased substantially (e.g. Akee, Basu, Bedi, \& Chau, 2010; Cho, 2015; Cho, Dreher, \& Neumayer, 2013; Hernandez \& Rudolph, 2015). ${ }^{12}$ The basic causes used in the modeling process of the MIMIC model are: (1) income per capita in logs, (2) foreign direct investment flows into destination countries (in logs), (3) employment in agriculture as a percentage of total employment in these countries, and (4) language fractionalization within the respective destination countries. The structural model is as follows:

$$
[\eta]=\left[\alpha_{1}, \alpha_{2}, \alpha_{3}, \alpha_{4}\right] \times\left[\begin{array}{c}
(\log ) \text { GDP pc } \\
(\log ) \text { FDI stock }_{i} \\
\text { employ agri }_{i} \\
\text { language fract }
\end{array}\right]+[\omega]
$$

(Ad1): The main economic reason behind the existence of both human traffickers and an easily exploited population is the movement of people from regions of lower labor productivity to those of higher productivity. Thus, the ideal destination country for human trafficking is a high-income country, which can accordingly become a breeding ground for this type of activity. We use income measured by GDP per capita (in logs) taken from the World Bank's (2012) Development Indicators (WDI) as a proxy for the economic pull factor.

$(\mathrm{Ad} 2)$ : It is noted that international investment relations lead to increased cultural, social, and economic interrelation between countries. These are therefore are an additional pull factor for human trafficking, which can be interpreted as the negative externality of increased international connectedness and as being facilitated by different aspects of globalization processes. Interconnect-

\footnotetext{
${ }^{9}$ We apply the overall index (3P-index) in order to avoid judging the importance of each of the single components. The fight against human trafficking is based on all three equally important aspects.

10 See Ditmore and Wijers (2003) for details on the negotiations of the Trafficking Protocol. For an example of media coverage see Spiegel Online (2014).

11 An overview of all variables used can be found in Table A1.

${ }^{12}$ All determinants used in the empirical literature so far are tested in the meta-study by Cho (2015) where she identifies robust causes of human trafficking flows. Contrary to Cho's approach, we focus on causal and indicating variables at the same time and apply the MIMIC model. In this way we add one layer of information to the one she uses. Nevertheless, the push and pull factors identified in Cho's study (2015) have been considered in various tests of our MIMIC model. In the final model we decided to focus on the determinants that have been robustly identified as causes of human trafficking in our setting and are in accordance with the model fit of our estimation technique.
} 
edness facilitates transport via the establishment of international trade routes and investment connections. International crime groups are large-scale business operations that are active in both the official and the informal economies, corrupting officials and legal networks (UNODC, 2010). The variable used is the share of foreign direct investment (FDI) (in logs), which shows these connections (UNCTAD, 2012)..$^{13}$

(Ad3): Most cases of human trafficking involve migrant workers in economic sectors such as agriculture and construction (Zhang, 2012). They account for 18 percent of identified cases of human trafficking according to the UNODC (2009). The increased chances of employment caused by the increased demand for cheap unskilled labor increases the attractiveness of countries as destinations for migrant workers (Hernandez \& Rudolph, 2015). ${ }^{14}$ In addition, high demand in the commercial sex market or other informal markets increases the probability of people being pushed towards these locations (Cho et al., 2013; Danailova-Trainor \& Belser, 2006; Jakobson $\&$ Kotsadam, 2013). Given the scarcity of data in this area, we are obliged to refrain from using sexual exploitation data and use agricultural employment given as a percentage of total employment, in data provided by the World Bank (2012). ${ }^{15}$

(Ad4): On the other hand, trafficking may be limited by technological advances and personal contacts. These increase the availability of information on migration opportunities and job offers and thus presumably reduce the risk of being trafficked. Therefore information flows should have a restricting effect on trafficking. We em- ploy the language component of the distance-adjusted ethno-linguistic fractionalization index (DELF) developed by Kollo $(2012)^{16}$ using the variable in the WDI data set (World Bank, 2012).

Figure 1 shows the respective path diagram and expected relations for the MIMIC model of human trafficking, which combines the measurement and the structural model.

\section{Results}

Before estimating the MIMIC models, we use multiple imputation with fixed country and year effects to balance the sample and control for unobserved factors. Subsequently, the MIMIC models are estimated using a maximum likelihood estimator with missing values. After testing for the robustness of the specification and evaluating the model fit, the final indices are generated for the years 2000 to 2010. In this way country rankings for every single country-year combination are generated, which makes it possible to assess the development of the extent of human trafficking over time. As discussed above, the decade 2000-2010 saw a rise in quantitative research on human trafficking, encouraged by the United Nations' official definition of trafficking in persons of 2000. Given the availability of data, the years between 2000 and 2010 appear to be the most useful for empirically exploring the major causes and indicators.

Since structural equation modeling (SEM) is confirmative in nature, the significance of variables is only one indication of model quality. When it is considered to-

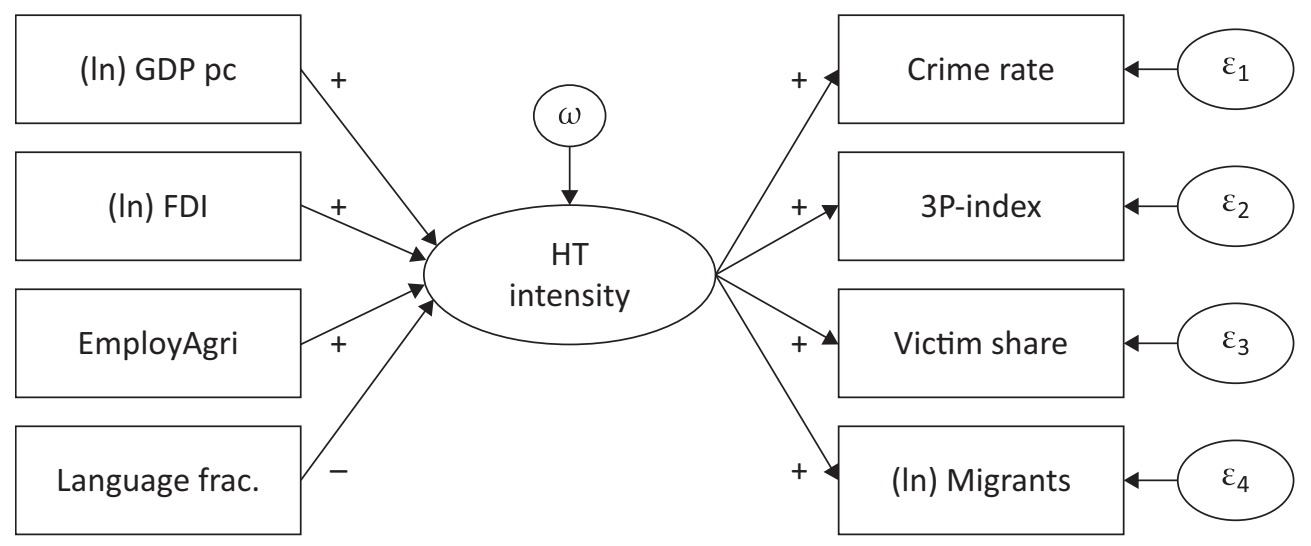

Figure 1. Path diagram of MIMIC models.

\footnotetext{
13 It has also been argued that spatial dependence works as a trigger for positive externalities such as the spillover effect of advancing women's rights (Neumayer \& De Soysa, 2011). We argue that this link can also act as a transport system for negative externalities, such as international criminal networks transporting human beings.

14 South-south migrants in particular have to rely on informal support systems rather than welfare benefits in their host countries, which makes them even more vulnerable (Avato, Koettle, \& Sabates-Wheeler, 2010).

15 We refer to Jakobson and Kotsadam (2016) for a detailed discussion of trafficking for sexual exploitation: its causes, indicators, and available data sources. Their analysis shows the scarcity of available data and supports our endeavour to develop a measure of human trafficking.

${ }^{16}$ This index accounts for (dis-)similarities between languages, which are crucial in human trafficking because potential victims are more vulnerable if the destination country's language is different from their own. These new data are an improvement on those of Cho (2015) and Akee, Basu, Chau, \& Khamis (2010) who use the ethnic fractionalization index (ELF) of Alesina et al. (2003). The ELF only considers the number of different languages in a country, thereby disregarding the crucial aspect of the distance between languages accounted for in the DELF. This is relevant in the context of the trafficking process. The results are not qualitatively different when the ELF index is employed.
} 
gether with the overall fit of the model, both these aspects are enough to reject or confirm the assumed relationships (Bollen, 1989). The judgment of the quality of the model is based on whether the estimated covariance is equal or close to the true sample covariance. ${ }^{17}$

\subsection{MIMIC Estimation Results}

Table 1 shows the results of the MIMIC estimation. The fit indicators show a good model fit. In particular, the chisquare statistic with a $p$-value of 0.02 indicates a good model fit. The results are point estimates. The observed correlation of GDP per capita is positive and significant at the 1 percent level, indicating that wealthier countries are more often the destination of human trafficking. Investment flows into destination countries are also positively associated with human trafficking (at the 5 percent significance level). More international business and investments are correlated with illicit human movement in the form of human trafficking. The robust positive relation observed (significant at the 1 percent level) to the share of employment in agriculture endorses the positive relation between human trafficking and opportunities for cheap employment (low skilled labor), which provides more potential placements for use by traffickers to exploit people. Linguistic fractionalization within countries has a negative and significant relation to trafficking at the 10 percent level. This suggests that less diverse countries pull more human trafficking into the country.

Turning to the measurement model, we find that all indicators match our expectations. One of the indicators of the latent variable has to be normalized and used as an anchor variable for the scale and identification: the crime rate. ${ }^{18}$ We follow the literature by using the indicator with the largest standardized coefficient $\left(0.891^{* * *}\right)$ as the anchor variable (e.g. Buehn \& Schneider, 2012; Dreher et al., 2007; Schneider et al., 2010). All four indicators are positively related to the extent of human trafficking, which is in line with theoretical considerations and economic intuition. The 3P-index of anti-trafficking policies turns positive and significant at the 1 percent level. This shows the importance of the extent of antitrafficking policies, which protect victims, prosecute traffickers, and prevent human trafficking, as a reflection of the intensity of human trafficking in the country. The number of identified victims as a share of the population is not statistically significant. The low quality of the data would explain this finding (Laczko \& Gozdziak, 2005). Finally and importantly, the share of migrants in the country positively indicates the prevalence of human trafficking (although this relation is not statistically significant at conventional levels).

We have carried out a number of robustness tests to check whether the results are valid under a variety of circumstances (Table 2 ). The results do not depend on the choice of estimation model and discount the three highest and lowest ranking countries (outliers) (Buehn \& Farzanegan, 2012). In order to rule out endogeneity concerns, we have also estimated the results following Dreher et al. (2007) and lagged all quantitative causal variables by one period before estimating the model. We have also followed Dreher et al. (2007) and tested whether it is a problem that some of the indicators could well be causal variables (such as the

Table 1. MIMIC estimates.

\begin{tabular}{|c|c|c|c|c|c|c|c|}
\hline \multicolumn{4}{|c|}{ Structural model (causes) } & \multicolumn{4}{|c|}{ Measurement model (indicators) } \\
\hline (In) GDP pc & (In) FDI & $\begin{array}{l}\text { Employment } \\
\text { in agriculture }\end{array}$ & $\begin{array}{l}\text { Language } \\
\text { fractionalization }\end{array}$ & Crime rate & $\begin{array}{l}\text { Overall } \\
\text { 3P-index }\end{array}$ & Victim share & (In) Migrants \\
\hline $\begin{array}{c}0.978 * * * \\
(6.656)\end{array}$ & $\begin{array}{c}0.172 * * \\
(2.248)\end{array}$ & $\begin{array}{c}0.438 * * * \\
(2.786)\end{array}$ & $\begin{array}{c}-0.124^{*} \\
(1.751)\end{array}$ & 1 & $\begin{array}{c}0.438 * * * \\
(6.000)\end{array}$ & $\begin{array}{c}0.036 \\
(0.302)\end{array}$ & $\begin{array}{c}0.118 \\
(1.105)\end{array}$ \\
\hline $\begin{array}{l}\text { Number } \\
\text { of countries }\end{array}$ & Chi-square & P-value & RMSEA & $\begin{array}{l}\text { Probability } \\
\text { RMSEA }<0.05\end{array}$ & $\mathrm{CFI}$ & TLI & $\mathrm{CD}$ \\
\hline 142 & 27.75 & 0.02 & 0.08 & 0.12 & 0.90 & 0.84 & 0.61 \\
\hline
\end{tabular}

Notes: Absolute z-statistics in parentheses; ${ }^{*} \mathrm{p}<0.1,{ }^{* *} \mathrm{p}<0.05,{ }^{* * *} \mathrm{p}<0.01$; The crime rate is chosen as the anchor variable and normalized to 1 . If the model fits the data perfectly and the parameter values are known, the sample covariance matrix equals the covariance matrix implied by the model with small Chi-square values. The root mean squared error of approximation (RMSEA) evaluates the fit of the model based on the deviance between the estimated and the real covariance. Brown and Cudeck (1993) assume that RMSEA values smaller than 0.05 imply a good model fit, which corresponds to a probability close to 1 . The two fit indices suggested by Bentler (1990) are the comparative fit index (CFI) and the Tucker-Lewis index (TLI). They indicate a good model fit with values close to 1 (Hu \& Bentler, 1999). The coefficient of determination (CD) is similar to the R-squared with higher values showing better fit.

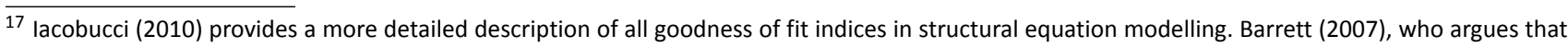
decision rules based on these indicators are arbitrary, provides a critical assessment of the use of goodness of fit indicators. He argues that the chisquare statistic is the "only substantive test of fit for SEM" (p. 815).

18 The choice of the anchor variable does not change estimation results qualitatively (Bollen, 1989). Tests show that this is true for the setting in this article as well.
} 
Table 2. MIMIC estimates (robustness tests).

\begin{tabular}{|c|c|c|c|c|}
\hline & & (1) & (2) & (3) \\
\hline \multirow[t]{7}{*}{$\begin{array}{l}\text { Structural model } \\
\text { (causes) }\end{array}$} & (In) GDP per capita & $\begin{array}{c}1.051 * * * \\
(5.497)\end{array}$ & $\begin{array}{c}0.721^{* * *} \\
(5.688)\end{array}$ & \\
\hline & (In) FDI & $\begin{array}{c}0.112 \\
(1.039)\end{array}$ & $\begin{array}{c}0.183 * * * \\
(2.869)\end{array}$ & \\
\hline & EmployAgri & $\begin{array}{l}0.391 * \\
(1.801)\end{array}$ & $\begin{array}{l}0.250^{*} \\
(1.867)\end{array}$ & \\
\hline & Language fract. & $\begin{array}{l}-0.159 \\
(1.628)\end{array}$ & $\begin{array}{l}-0.093 \\
(1.583)\end{array}$ & $\begin{array}{c}-0.127^{*} \\
(1.784)\end{array}$ \\
\hline & lagged (In) GDP pc & & & $\begin{array}{c}0.968^{* * *} \\
(6.686)\end{array}$ \\
\hline & lagged (In) FDI & & & $\begin{array}{r}0.177^{* *} \\
(2.333)\end{array}$ \\
\hline & lagged EmployAgri & & & $\begin{array}{c}0.432 * * * \\
(2.795)\end{array}$ \\
\hline \multirow{4}{*}{$\begin{array}{l}\text { Measurement model } \\
\text { (indicators) }\end{array}$} & Crime rate & 1 & 1 & 1 \\
\hline & Overall 3P-index & $\begin{array}{c}0.633 * * * \\
(6.773)\end{array}$ & $\begin{array}{c}0.706 * * * \\
(5.053)\end{array}$ & $\begin{array}{c}0.686^{* * *} \\
(6.014)\end{array}$ \\
\hline & Share of victims & $\begin{array}{c}0.038 \\
(0.319)\end{array}$ & $\begin{array}{l}-0.082 \\
(0.567)\end{array}$ & $\begin{array}{c}0.035 \\
(0.298)\end{array}$ \\
\hline & (In) Migrants & $\begin{array}{c}0.289 * * \\
(2.432)\end{array}$ & $\begin{array}{c}0.028 \\
(0.220)\end{array}$ & $\begin{array}{c}0.117 \\
(1.107)\end{array}$ \\
\hline \multirow[t]{2}{*}{ Fit statistics } & Number of countries & 84 & 136 & 142 \\
\hline & Chi-square & 30.89 & 28.17 & 26.96 \\
\hline
\end{tabular}

Notes: Absolute z-statistics in parentheses; ${ }^{*} \mathrm{p}<0.1,{ }^{* *} \mathrm{p}<0.05,{ }^{* * *} \mathrm{p}<0.01$; Explanation of fit statistics see Table 1.

crime rate or migration). ${ }^{19}$ The results are qualitatively unchanged. ${ }^{20}$

\subsection{Human Trafficking Index}

The human trafficking index provides an assessment of human trafficking relative to other countries in all dimensions of the process. As described in Section 2, human trafficking includes all forms of exploitation and all groups of actors involved, traffickers as well as victims. We focus on the destination countries where exploitation takes place. Thus, we conceive of the extent of human trafficking in these countries as a bundle of actions and decisions. This includes the decision of traffickers to send individuals to these countries and exploit them. Additionally, it includes the extent of a market failure which provides opportunities for the exploitation of victims through the demand for cheap labor as well as the share of the population which is vulnerable and marginalized and therefore easily exploited. This shows that creating a clear picture of the extent and dimensions of human trafficking in countries is still very difficult. However, the derived index and subsequent ranking of countries is superior to existing measurements of specific aspects of human trafficking. For example, the tier score of the U.S. Department of State (2001, 2002, 2003, 2004, 2005, 2006, 2007, 2008, 2009, 2010, 2011, 2012), which only addresses compliance with U.S. policies, has been criticized as a one-sided approach that reflects political interest rather than the will to produce a transparent independent score of the variety of international policy approaches (Simmons \& Lloyd, 2010). ${ }^{21}$ By contrast, the underlying data implemented in the construction of our intensity index (human trafficking index) are based on publicly available data of causes and indicators that influence human trafficking by the means which have been described.

The relevance of the measure is assessed in the following Table 3, where we show the pairwise correlations of the human trafficking index with the 3P-antitrafficking policy index, the tier rank of the U.S. Department of State, and the citation index compiled by the UNODC (2006, 2009, 2012). ${ }^{22}$

\footnotetext{
19 These results are available from the authors upon request.

${ }^{20}$ An important issue in using the MIMIC approach is whether the assumption that the variables identify one latent factor holds. Using a principal component analysis (PCA), results show that one component is sufficiently explained by the variation in variables, suggesting that our assumption of one latent factor (human trafficking intensity) holds.

21 Simmons and Lloyd (2010) criticize the ranking of countries by the Department of State for mirroring the political interests of the U.S.A. and suggest that it eventually serves to get other countries to comply with the norms set out by the country depicted as the world's referee.

22 We do not include the Global Slavery Index in our assessment here, since it mainly refers to countries where victims originate.
} 
Table 3. Pairwise correlations of human trafficking indices.

\begin{tabular}{llllll}
\hline & Human trafficking index & Overall 3P-index & Tier rank & $\mathrm{Cl}$ : destination & $\mathrm{Cl}$ : origin \\
\hline Human trafficking index & 1 & & & & \\
Overall 3P-index & $0.6647^{*}$ & 1 & & & \\
Tier rank & $0.5910^{*}$ & $0.7290^{*}$ & $0.2787^{*}$ & 1 & \\
$\mathrm{Cl}$ destination & $0.4912^{*}$ & $0.3835^{*}$ & $-0.1762^{*}$ & $-0.0743^{*}$ & 1 \\
$\mathrm{Cl}$ : origin & $-0.3868^{*}$ & -0.0493 & -1 & \\
\hline
\end{tabular}

Notes: ${ }^{*} p<0.01$; The tier rank is reversed and shows higher values the better countries fulfil the Victims of Trafficking and Violence Protection Act (TVPA) standards. CI: destination/origin refers to the citation index compiled by the UNODC. The countries are ranked in a five-category scale with the highest value indicating that the probability of being a destination/origin country is "very high".

The correlations show that the human trafficking index has a high positive correlation with the 3P-index. Countries that rank high in fighting human trafficking have a higher intensity of trafficking inflows (as assumed in Section 2 and shown in Table 2). Similarly, we see a positive correlation between the tier rank and the citation index of destination countries, as well as a negative correlation to the citation index of countries of origin. One could argue that the correlation between the latter three indices is only modest ( 0.59 to 0.39 , respectively). However, this is attributed to the different aspects of human trafficking that they measure. The tier rank addresses compliance with the TVPA and thus political decisions to fight human trafficking. This is only one aspect of the process of trafficking in human beings and a partial aspect of our intensity index, which also captures country characteristics, as well as the criminal dimension and vulnerability of victims. The same holds true for the citation indices: both indices capture aspects of human trafficking which are visible to society and therefore receive public attention. In the MIMIC model the crime rate, numbers of identified victims, and migration levels are used as indicators and combined with the causes-this ensures that this aspect of the trafficking process is included in the intensity index to provide a holistic picture.

\subsection{Country Rankings}

Looking at Table 4 we find mainly OECD countries leading the ranking of destination countries. The table shows the twenty top and bottom ranking countries in the years 2001, 2005, 2010. At the lower end of the ranking, we find Asian, Latin-American and Sub-Saharan African countries with a low prevalence of trafficking into their countries.

Unsurprisingly industrialized countries are at the top of the ranking. This is in line with the observations in the UNODC report (2006, p. 17). Countries in North America and Europe, as well as Australia are reported to be the top destination countries for human trafficking. The fact that Scandinavian countries rank so highly indicates that there are hidden activities taking place in these countries which enable traffickers to exploit individuals. This is less surprising than it seems when their geographical location is taken into account, particularly considering that they are often used as role models for institutional quality. They are close to Russia and Eastern European countries, which have lower economic opportunities and, in Russia's case at times, a higher level of persecution of individuals (traffickers and victims alike). Thus, they are very attractive destinations for the vulnerable and desperate in these countries as well as Middle Eastern, African, and Asian nations. It is also in line with the observation that the share of identified victims in these countries is quite high, especially at the beginning of the century. ${ }^{23}$

Looking at major OECD countries, the United Statesthe country which has pushed initiatives against human trafficking such as the implementation of anti-trafficking instruments-consistently ranks among the top 20 countries and even leads the ranking in 2010. This relatively constant position suggests that despite the United States' intense anti-trafficking efforts and awareness campaigns run locally and internationally, the magnitude of the problem within its borders seems to be stable and has even worsened recently with a higher intensity in 2010 (index value of 79). Finally, Germany ranks among the top ten countries throughout the years, which confirms reports of a high magnitude of human trafficking in the country.

At the lower end of the list are mainly low-income countries, which act as a source rather than a destination for victims of human trafficking. There are some (rather surprising) variations in the ranking of some countries. We attribute these to different aspects of the trafficking process. Firstly, from the perspective of the traffickers, it should make sense to use established trafficking routes. However, as a way of hiding from criminal justice systems, variations in destination countries may serve to reduce the chances of getting caught. Secondly, from the perspective of the victims, the same holds true for migration routes and observed travel patterns. Finally, from the perspective of a state fighting human trafficking, a series of legal successes in one year may serve to make the problem more visible but may not be repeated in the next. In countries such as Brunei Darussalam or the United Arab Emirates, an autocratic state may be able to

\footnotetext{
23 The share of victims in Iceland and Norway in 2000 was 10.4 per 100,000 people, which is one of the highest shares of identified victims across all countries during the decade observed.
} 
Table 4. Highest and lowest ranking countries in specific years.

\begin{tabular}{|c|c|c|c|c|c|c|c|c|}
\hline Country & Rank & 2001 & Country & Rank & 2005 & Country & Rank & 2010 \\
\hline \multicolumn{9}{|c|}{ highest ranking countries } \\
\hline Belgium & 1 & (89) & United Kingdom & 1 & $(83)$ & United States & 1 & (79) \\
\hline Iceland & 2 & (87) & Netherlands & 2 & (81) & Canada & 2 & (75) \\
\hline Netherlands & 3 & (85) & Norway & 3 & (81) & Switzerland & 3 & (72) \\
\hline Germany & 4 & (84) & Belgium & 4 & (79) & Norway & 4 & (72) \\
\hline Luxembourg & 5 & (83) & Sweden & 5 & (78) & France & 5 & $(72)$ \\
\hline Sweden & 6 & (83) & Germany & 6 & (77) & United Kingdom & 6 & (72) \\
\hline Denmark & 7 & (81) & Denmark & 7 & (77) & Brunei Darussalam & 7 & $(72)$ \\
\hline Switzerland & 8 & (81) & Luxembourg & 8 & (77) & Australia & 8 & (72) \\
\hline Norway & 9 & (81) & Australia & 9 & (75) & Germany & 9 & (71) \\
\hline Canada & 10 & (80) & Iceland & 10 & (75) & Luxembourg & 10 & (71) \\
\hline United Kingdom & 11 & (79) & Ireland & 11 & (75) & Sweden & 11 & (71) \\
\hline Ireland & 12 & (78) & Switzerland & 12 & (75) & Belgium & 12 & (71) \\
\hline Austria & 13 & (78) & Austria & 13 & (74) & Qatar & 13 & (71) \\
\hline Finland & 14 & (76) & France & 14 & (73) & Israel & 14 & (71) \\
\hline France & 15 & (76) & Spain & 15 & (73) & Netherlands & 15 & (71) \\
\hline Brunei Darussalam & 16 & (76) & Italy & 16 & (72) & Ireland & 16 & (70) \\
\hline Spain & 17 & (75) & Portugal & 17 & (72) & United Arab Emirates & 17 & (70) \\
\hline United States & 18 & (73) & New Zealand & 18 & (71) & Austria & 18 & (69) \\
\hline Australia & 19 & (73) & United States & 19 & (71) & Italy & 19 & (69) \\
\hline The Bahamas & 20 & $(72)$ & Finland & 20 & (70) & Denmark & 20 & $(68)$ \\
\hline \multicolumn{9}{|c|}{ lowest ranking countries } \\
\hline Philippines & 122 & (36) & Peru & 122 & (36) & Sierra Leone & 122 & (37) \\
\hline Kenya & 123 & (35) & Kyrgyz Republic & 123 & (36) & Bangladesh & 123 & (37) \\
\hline Gambia & 124 & (34) & Uganda & 124 & (35) & Yemen & 124 & (37) \\
\hline Nepal & 125 & (34) & Gambia & 125 & (35) & Vietnam & 125 & (36) \\
\hline Uzbekistan & 126 & (34) & Bolivia & 126 & (35) & Zambia & 126 & (36) \\
\hline Liberia & 127 & (34) & Nepal & 127 & (34) & Uganda & 127 & (36) \\
\hline Kyrgyz Republic & 128 & (31) & Kenya & 128 & (33) & Tajikistan & 128 & (36) \\
\hline Mali & 129 & (31) & Sierra Leone & 129 & (33) & Cambodia & 129 & (36) \\
\hline Iran & 130 & (30) & Mali & 130 & (31) & Gambia & 130 & (36) \\
\hline Uganda & 131 & (30) & Madagascar & 131 & (31) & Kyrgyz Republic & 131 & (36) \\
\hline Sierra Leone & 132 & (28) & Algeria & 132 & (31) & Tanzania & 132 & (36) \\
\hline Senegal & 133 & (26) & Syria & 133 & (31) & Mongolia & 133 & (36) \\
\hline Sudan & 134 & (26) & Ethiopia & 134 & (30) & Lesotho & 134 & (35) \\
\hline Malawi & 135 & (25) & Sudan & 135 & (30) & Ethiopia & 135 & (35) \\
\hline Niger & 136 & (24) & Senegal & 136 & (29) & Niger & 136 & (34) \\
\hline Burundi & 137 & (23) & Ghana & 137 & (28) & Mozambique & 137 & (32) \\
\hline Ethiopia & 138 & (23) & Iraq & 138 & (27) & Zimbabwe & 138 & (31) \\
\hline Tajikistan & 139 & (23) & Niger & 139 & (25) & Malawi & 139 & (28) \\
\hline Ghana & 140 & (23) & Burundi & 140 & (25) & Liberia & 140 & (27) \\
\hline Madagascar & 141 & (20) & Liberia & 141 & (20) & Burundi & 141 & (25) \\
\hline Cuba & 142 & (12) & Cuba & 142 & (7) & Madagascar & 142 & $(22)$ \\
\hline
\end{tabular}

Note: The columns indicate the ranks of the countries and their respective index scores (in parentheses) on a scale from 1 to 100 in the years 2001, 2005, and 2010.

hide the problem from the public eye more effectively than democratic states with checks and balances.

\section{Conclusion}

Human trafficking is a global phenomenon of large proportions. People are exploited, live in inhumane condi- tions, and lack food or access to health facilities, especially in high-income countries. The article disentangles the relationships between indicators and causes of human trafficking by employing a structural equation approach (MIMIC) and ranking 142 countries over a tenyear period according to the prevalence of human trafficking within their borders. 
Our approach goes beyond existing studies by including both causal factors and indicators while acknowledging the illicit nature of the phenomenon. The causes mirror the incentive structure for traffickers, which is intended to maximize their chances of making high profits while maintaining a low probability of detection. Furthermore, the causes also capture the vulnerability of trafficking victims by addressing their incentives to move in the first place, a decision which leaves them vulnerable to false promises of better opportunities. By travelling from a poorer country to a wealthier one, individuals are inherently vulnerable: this is especially the case as linguistic fractionalization is negatively related to intensity. The indicators, on the other hand, show the results in countries where illegal trafficking of human beings takes place. Human trafficking is observed in countries with high crime levels, e.g. a larger underground economy running parallel to migration flows. The numbers of identified victims together with the number of migrants are indicators of the phenomenon and describe the visible extent of the problem. The dimensions of the fight against human trafficking (3P-index) quantify the application of anti-trafficking policies within countries.

The pattern of the development of human trafficking over the observed period is in line with expectations. Developed countries rank high and display a large amount of trafficking within their borders. These countries are the primary targets for traffickers, presumably because the potential for large profits is greatest in wealthier countries. The lowest ranking countries are mainly countries in Sub-Saharan Africa, Asia, and Latin America, where many people flee their miserable living conditions and look for other opportunities in more prosperous countries.

In terms of policy implications, we highlight that we have estimated a country-specific measurement. One should keep in mind that human trafficking is a transnational problem and that the fight against this crime is best conducted at both ends of the trafficking route: in both destination and source countries in a coherent manner across policy fields and jurisdictions. Additionally, the allocation of resources on the supranational level, e.g. to Interpol or other international organizations, might be best suited to address and fight all aspects of human trafficking.

\section{Acknowledgements}

We would like to thank the editor and two referees for their helpful comments and suggestions for the final version of this article. In addition, we would like to thank Axel Dreher, Pierre-Guillaume Méon, the participants of the International and Development policy seminar, Heidelberg, especially Maya Schmaljohann, Vera Eichenauer, Matthias Hartmann and Martin Breßlein, as well as participants at the European Public Choice Society meeting 2013, Zurich and of the Beyond Basic Questions Workshop 2013, Luzern, for their helpful comments on an earlier version of this article. We thank Jamie Parsons and Claudia Witkowski for helpful proofreading.

\section{Conflict of Interests}

Both authors certify that they have no affiliations with or involvement in any organization or entity with any financial interest (such as honoraria; educational grants; participation in speakers' bureaus; membership, employment, consultancies, stock ownership, or other equity interest; and expert testimony or patent-licensing arrangements), or non-financial interest (such as personal or professional relationships, affiliations, knowledge or beliefs) in the subject matter or materials discussed in this manuscript.

\section{References}

Akee, R., Basu, A., Bedi, A., \& Chau, N. (2010). Determinants of trafficking in women and children: crossnational evidence, theory and policy implications. In G. S. Epstein \& I. N. Gang (Eds.), Migration and culture: Frontiers of economics and lobalization. Bingley: Emerald.

Akee, R., Basu, A., Chau, N., \& Khamis, M. (2010). Ethnic fragmentation, conflict, displaced persons and human trafficking: An empirical analysis. In G. S. Epstein \& I. N. Gang (Eds.), Migration and culture: frontiers of economics and globalization (pp. 691-716). Bingley: Emerald.

Alesina, A., Devleeschauwer, A., Easterly, W., Kurlat, S., \& Wacziarg, R. (2003). Fractionalization. Journal of Economic Growth, 8(2), 155-194.

Avato, J., Koettle, J., \& Sabates-Wheeler, R. (2010). Social security regimes, global estimates, and good practices: The status of social protection for international migrants. World Development, 38(4), 455-466.

Barrett, P. (2007). Structural equation modelling: Adjudging model fit. Personality and Individual Differences, $42,815-824$.

Belser, P. (2005). Forced labour and human trafficking: Estimating the profits (ILO Working Paper No. 42). Geneva: International Labor Organization.

Bentler, P. M. (1990). Comparative fit indexes in structural models. Psychological Bulletin, 107, 238-246.

Betti, S. (2001). The European Union and the United Nations convention against transnational organised crime (Civil Liberties Series LIBE116EN). Brussels: Directorate-General for Research, European Parliament.

Bollen, K. A. (1989). Structural equations with latent variables. New Jersey: John Wiley \& Sons.

Brown, M. W., \& Cudeck, R. (1993). Alternative ways of assessing model fit. In K. A. Bollen and J. S. Long, Sage (Eds.), Testing structural equation models (pp. 445455). Newbury Park, CA: Sage.

Buehn, A. (2012). The shadow economy in German regions: An empirical assessment. German Economic Review, 13(3), 275-290. 
Buehn, A., \& Eichler, S. (2009). Smuggling illegal versus legal goods across the U.S.-Mexico border: A structural equations model approach. Southern Economic Journal, 76(2), 328-350.

Buehn, A., \& Farzanegan, M. R. (2012). Smuggling around the world: Evidence from a structural equation model. Applied Economics, 44, 3047-3064.

Buehn, A., \& Farzanegan, M. R. (2013). Hold your breath: A new index of air pollution. Energy Economics, 37, 104-113.

Buehn, A., \& Schneider, F. (2012). Shadow economies around the world: Novel insights, accepted knowledge, and new estimates. International Tax and Public Finance, 19, 139-171.

Burstein, P. (2003). The impact of public opinion on public policy: A review and an agenda, Political Research Quarterly, 56, 29-40.

Cho, S. Y. (2015). Modeling for determinants of human trafficking. Social Inclusion, 3(1), 2-21.

Cho, S. Y., Dreher, A., \& Neumayer, E. (2013). Does legalization of prostitution increase human trafficking? World Development, 41, 67-82.

Cho, S. Y., Dreher, A., \& Neumayer, E. (2014). The determinants of anti-trafficking policies: Evidence from a new index. Scandinavian Journal of Economics, 116(2), 429-454.

Cliff, N. (1983). Some cautions concerning the application of causal modeling methods. Multivariate Behavioral Research, 18, 115-126.

Danailova-Trainor, G., \& Belser, P. (2006). Globalization and the illicit market for human trafficking: An empirical analysis of supply and demand (ILO Working Paper No. 78). Geneva: International Labor Organization.

Di Tommaso, M., Raiser, M., \& Weeks, M. (2007). Home grown or imported? Initial conditions, external anchors and the determinants of institutional reform in the transition economies. The Economic Journal, 117, 858-881.

Ditmore, M., \& Wijers, M. (2003). The negotiations on the UN Protocol on trafficking in persons. Nemesis, 4 , 79-88.

Dreher, A., Kotsogiannis, C., \& McCorriston, S. (2007). Corruption around the world: Evidence from a structural model. Journal of Comparative Economics, 35(3), 443-466.

Frey, B., \& Weck-Hanneman, H. (1984). The hidden economy as an unobserved variable. European Economic Review, 26, 33-53.

Gallagher, A. T. (2009). Human rights and human trafficking: Quagmire or firm ground? A response to James Hathaway. Virginia Journal of International Law, 49(4), 789-848.

Hathaway, O. (2007). Why do countries commit to human rights treaties? Journal of Conflict Resolution, 51(4), 588-621.

Hernandez, D., \& Rudolph, A. (2015). Modern day slavery: What drives human trafficking in Europe? European Journal of Political Economy, 38, 118-139.
Hu, L. T., \& Bentler, P. M. (1999). Cutoff criteria for fit indexes in covariance structure analysis: conventional criteria versus new alternatives. Structural Equation Modeling, 6(1), 1-55.

lacobucci, D. (2010). Structural equations modeling: Fit Indices, sample size, and advanced topics. Journal of Consumer Psychology, 20, 90-98.

ILO. (2005). A global alliance against forced labour, global report under the follow-up to the ILO declaration on fundamental principles and rights at work. Geneva: International Labour Conference.

Interpol. (2012). Fact sheet on human trafficking. Retrieved from www.interpol.int/Crime-areas/Traffick ing-in-human-beings/Trafficking-in-human-beings

Jakobson, N., \& Kotsadam, A. (2013). The law and economics of international sex slavery: Prostitution laws and trafficking for sexual exploitation. European Journal of Law and Economics, 35(1), 87-107.

Jakobson, N., \& Kotsadam, A. (2016). The economics of trafficking for sexual exploitation. In S. Cunningham \& M. Shah (Eds.), The Oxford handbook of the economics of prostitution (pp. 462-476). Oxford University Press.

Jöreskog, K. G., \& Goldberger, A. S. (1975). Estimation of a model with multiple indicators and multiple causes of a single latent variable. Journal of the American Statistical Association, 70, 631-639.

Kollo, P. (2012). Measuring ethnicity: The appropriate diversity index (IAI Discussion Papers No. 221). Göttingen: Ibero America Institute for Economic Research.

Kuklys, W. (2004). Measuring standard of living in the UK: An application of sens functioning approach using structural equation models (Working Paper on Strategic Interaction No. 11). Jena: Max Planck Institute.

Laczko, F., \& Gozdziak, E. (2005). Data and research on human trafficking: A global survey. Geneva: International Organization for Migration.

Loayza, N. V. (1996). The economics of the informal sector: A simple model and some empirical evidence from Latin America. Carnegie-Rochester Conference Series on Public Policy, 45, 129-162.

Neumayer, E., \& De Soysa, I. (2011). Globalization and the empowerment of women: An analysis of spatial dependence via trade and foreign direct investment. World Development, 39(7), 1065-1075.

Salt, J. (2000). Trafficking and human smuggling: A European perspective. International Migration, 38, 31-56.

Salt, J., \& Stein, J. (1997). Migration as a business: The case of trafficking. International Migration, 35(4), 467-494.

Schloenhardt, A. (2001). Trafficking in migrants: Illegal migration and organized crime in Australia and the Asia Pacific region. International Journal of the Sociology of Law, 29, 331-378.

Schneider, F., \& Enste, D. H. (2000). Shadow economies: Size, causes and consequences. Journal of Economic Literature Journal, 38, 77-114. 
Schneider, F., \& Enste, D. H. (2002). The shadow economy: An international survey. Cambridge University Press.

Schneider, F., Buehn, A., \& Montenegro, C.E. (2010). Shadow economies all over the world: New estimates for 162 countries from 1999 to 2007 (World Bank Policy Research Working Paper No. 5356). Retrieved from https://papers.ssrn.com/sol3/papers.cfm?ab stract_id $=1645726$

Shelley, L. I. (1999). Identifying, counting and categorizing transnational criminal organizations. Transnational Organized Crime, 5(1), 1-18.

Simmons, B. (2000). International law and state behavior: Commitment and compliance in international monetary affairs. American Political Science Review, 94(4), 819-835.

Simmons, B., \& Lloyd, P. (2010). Subjective frames and rational choice: Transnational crime and the case of human trafficking. Retrieved from https://www. researchgate.net/publication/228151405_Subjective _Frames_and_Rational_Choice_Transnational_Crime _and_the_Case_of_Human_Trafficking

Spiegel Online (2014). Menschenhandel: Deutschland hin und zurück. Retrieved from www.spiegel.de/ sptv/-extra/a-96636.html

Tyldum, G., \& Brunovskis, A. (2005). Describing the unobserved: Methodological challenges in empirical studies on human trafficking. In F. Laczko \& E. Gozdziak (Eds.), Data and research on human trafficking: $A$ global survey (pp. 17-34). Geneva: International Organization of Migration.

United Nations. (2000). Protocol to prevent, suppress and punish trafficking in persons, especially women and children, supplementing the United Nations Convention against transnational organized crime. New York: United Nations.

UNCTAD. (2012). United Nations Conference on Trade and Development Statistics. Retrieved from http://unctadstat.unctad.org/ReportFolders/report Folders.aspx

UNODC (2006). Trafficking in persons, global patterns. Vienna: United Nations Office on Drugs and Crime.

UNODC (2008). Surveys on crime trends and operations of criminal justice systems (UN-CTS). Vienna: United Nations Office on Drugs and Crime.

UNODC (2009). Global report on trafficking in persons. Human trafficking a crime that shames us all. Vienna: United Nations Office on Drugs and Crime.

UNODC (2010). The globalization of crime: A transnational organized crime assessment. Vienna: United Nations Office on Drugs and Crime.

UNODC (2012). Global report on trafficking in persons. Vienna: United Nations Office on Drugs and Crime.

U.S. Department of State. (2001). Trafficking in persons report. Washington, DC: Office of the Undersecretary for Global Affairs. United States Department of State Publication.

U.S. Department of State. (2002). Trafficking in persons report. Washington, DC: Office of the Undersecretary for Global Affairs. United States Department of State Publication.

U.S. Department of State. (2003). Trafficking in persons report. Washington, DC: Office of the Undersecretary for Global Affairs. United States Department of State Publication.

U.S. Department of State. (2004). Trafficking in persons report. Washington, DC: Office of the Undersecretary for Global Affairs. United States Department of State Publication.

U.S. Department of State. (2005). Trafficking in persons report. Washington, DC: Office of the Undersecretary for Global Affairs. United States Department of State Publication.

U.S. Department of State. (2006). Trafficking in persons report. Washington, DC: Office of the Undersecretary for Global Affairs. United States Department of State Publication.

U.S. Department of State. (2007). Trafficking in persons report. Washington, DC: Office of the Undersecretary for Global Affairs. United States Department of State Publication.

U.S. Department of State. (2008). Trafficking in persons report. Washington, DC: Office of the Undersecretary for Global Affairs. United States Department of State Publication.

U.S. Department of State. (2009). Trafficking in persons report. Washington, DC: Office of the Undersecretary for Global Affairs. United States Department of State Publication.

U.S. Department of State. (2010). Trafficking in persons report. Washington, DC: Office of the Undersecretary for Global Affairs. United States Department of State Publication.

U.S. Department of State. (2011). Trafficking in persons report. Washington, DC: Office of the Undersecretary for Global Affairs. United States Department of State Publication.

U.S. Department of State. (2012). Trafficking in persons report. Washington, DC: Office of the Undersecretary for Global Affairs. United States Department of State Publication.

U.S. Department of State. (2013). Trafficking in persons report. Washington, DC: Office of the Undersecretary for Global Affairs. United States Department of State Publication.

Walk Free Foundation. (2013). The Global Slavery Index. Retrieved from www.globalslaveryindex.org

Werb, D., Rowell, G., Guyatt, G., Kerr, T., Montaner, J., \& Wood, E (2011). Effect of drug law enforcement on drug market violence: A systematic review. International Journal of Drug Policy, 22(2), 87-94.

World Bank. (2012). World development indicators. Washington, DC: World Bank.

Zhang, S. X. (2012). Measuring labor trafficking: A research note. Crime Law and Social Change, 58(4), 469-482. 


\section{About the Authors}

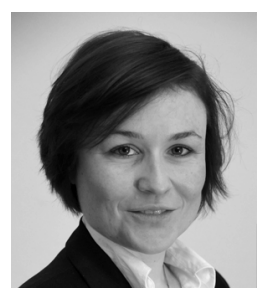

Alexandra Rudolph (PhD) is senior researcher at the German Development Institute in Bonn, Germany. She specialises in development economics and international political economy, covering topics on globalization, the economics of human trafficking, development aid and aid effectiveness, as well as social security in developing countries and ecological economics. She did her PhD in Economics in 2015 at the Ruprecht-Karl-University in Heidelberg and studied European Economic Studies at the Otto-Friedrich University in Bamberg.

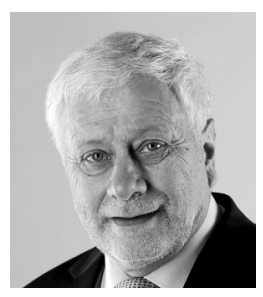

Friedrich Schneider (PhD) is Professor of Economics at the Johannes Kepler University of Linz, Austria. He has held numerous visiting and honorary positions at a number of universities and he was the European editor of Public Choice from 1991 to 2004. He has published extensively in leading economics journals including The Quarterly Journal of Economics, The American Economic Review, and The Economic Journal. He has published (1974-May 2017) 80 books, 238 articles in scientific journals and 196 articles in edited volumes. 


\section{Appendix}

Table A1. Data and sources.

\begin{tabular}{|c|c|c|}
\hline Variables & Description & Sources \\
\hline (log) GDP per capita & GDP per capita in constant US\$ (2005) & World Bank (2012) \\
\hline (log) FDI stock share & Inward and outward FDI stock as percentage of GDP & UNCTAD (2012) \\
\hline $\begin{array}{l}\text { Employment in agriculture } \\
\text { (percent of total) }\end{array}$ & $\begin{array}{l}\text { Share of employment in agriculture as percentage } \\
\text { of total employment }\end{array}$ & World Bank (2012) \\
\hline $\begin{array}{l}\text { International migrants } \\
\text { (share) }\end{array}$ & $\begin{array}{l}\text { Number of (officially registered) international migrants } \\
\text { in the country as share of total population }\end{array}$ & World Bank (2012) \\
\hline $\begin{array}{l}\text { Refugees by country } \\
\text { of origin }\end{array}$ & $\begin{array}{l}\text { Number of (officially registered) refugees in the country } \\
\text { per } 100,000 \text { of local population }\end{array}$ & World Bank (2012) \\
\hline $\begin{array}{l}\text { East Asia and the Pacific } \\
\text { (region dummy) }\end{array}$ & $\begin{array}{l}\text { Dummy indicating countries lying in East Asia and the } \\
\text { Pacific region according to the World Bank }\end{array}$ & World Bank (2012) \\
\hline Linguistic fractionalization & $\begin{array}{l}\text { Linguistic fractionalization in countries as part of the distance } \\
\text { adjusted ethno-linguistic fractionalization index (DELF); 0-1, } \\
\text { larger values indicating larger linguistic dissimilarities }\end{array}$ & $\begin{array}{l}\text { Kollo (2012), } \\
\text { Alesina et al. (2003) }\end{array}$ \\
\hline Crime rate & Crime rate in the country per 100,000 people & UNODC (2008) \\
\hline OECD membership & Dummy for OECD countries & OECD (2012) \\
\hline Victims & $\begin{array}{l}\text { Number of identified human trafficking victims in destination } \\
\text { countries coded by the UNODC in their Global Report on } \\
\text { Trafficking in Persons }\end{array}$ & UNODC $(2009,2012)$ \\
\hline $\begin{array}{l}\text { 3P-anti-trafficking index } \\
\text { and sub-components } \\
\text { (prosecution, protection, } \\
\text { prevention) }\end{array}$ & $\begin{array}{l}\text { Anti-trafficking policy index which shows the application of } \\
\text { anti-trafficking instruments in countries; } 3-15 \text {, larger values } \\
\text { indicating more compliance; Sub-components are the policy } \\
\text { instruments applicable ranging from } 1-5\end{array}$ & $\begin{array}{l}\text { Cho, Dreher and } \\
\text { Neumayer (2014) }\end{array}$ \\
\hline
\end{tabular}


Table A2. Country ranking and index (2000-2010).

\begin{tabular}{|c|c|c|c|c|c|c|c|c|c|c|c|c|c|c|c|c|c|c|c|c|c|c|}
\hline iou & 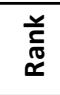 & চ্ণ & 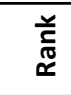 & ఫ્ડ & 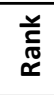 & ণั่ & 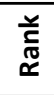 & ஜ̊ํ & 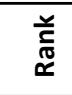 & ষ্ণ & $\begin{array}{l}\text { 弟 } \\
\text { 『̋ }\end{array}$ & 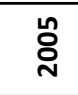 & 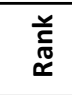 & ๕ั & 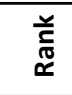 & ఫ్రి & 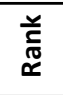 & : & 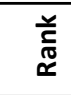 & ઠి & 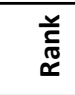 & 윰 \\
\hline nited Kingdom & 9 & (79) & 11 & (79) & 4 & (90) & 4 & (79) & 5 & (79) & 1 & (83) & 1 & (76) & 7 & (73) & 10 & (71) & 5 & $(81)$ & 6 & $(72)$ \\
\hline etherlands & 7 & (79) & 3 & (85) & 8 & (86) & 9 & (76) & 7 & (78) & 2 & (81) & 3 & (75) & 3 & (76) & 6 & (74) & 4 & $(81)$ & 15 & (71) \\
\hline orway & 12 & (78) & 9 & $(81)$ & 3 & (90) & 1 & (81) & 1 & (96) & 3 & (81) & 8 & $(72)$ & 8 & (73) & 7 & (74) & 2 & $(83)$ & 4 & $(72)$ \\
\hline elgium & 5 & (81) & 1 & (89) & 2 & (91) & 6 & (78) & 9 & (76) & 4 & (79) & 7 & (72) & 2 & (76) & 2 & (78) & 3 & $(83)$ & 12 & (71) \\
\hline weden & 13 & (77) & 6 & (83) & 10 & (84) & 7 & (76) & 12 & (74) & 5 & (78) & 4 & (75) & 6 & (75) & 5 & (75) & 1 & (85) & 11 & (71) \\
\hline ermany & 8 & (79) & 4 & (84) & 6 & (87) & 3 & (79) & 2 & $(82)$ & 6 & (77) & 11 & (70) & 16 & (67) & 18 & (66) & 11 & (76) & 9 & (71) \\
\hline enmark & 16 & (76) & 7 & (81) & 5 & (88) & 2 & (81) & 10 & (75) & 7 & (77) & 5 & (73) & 5 & (75) & 4 & (77) & 9 & (79) & 20 & (68) \\
\hline uxen & 6 & (79) & 5 & (83) & 7 & (86) & 8 & (76) & 18 & (70) & 8 & (77) & 6 & (73) & 4 & (76) & 1 & (79) & 7 & (81) & 10 & (71) \\
\hline ustralia & 17 & (75) & 19 & (73) & 18 & (73) & 14 & (74) & 3 & (82) & 9 & (75) & 16 & (68) & 13 & (68) & 13 & (68) & 8 & (79) & 8 & (72) \\
\hline eland & 25 & (71) & 2 & (87) & 1 & $(100)$ & 12 & (74) & 22 & (67) & 10 & (75) & 2 & (75) & 1 & (81) & 3 & (77) & 6 & $(81)$ & 29 & (63) \\
\hline eland & 15 & (76) & 12 & (78) & 12 & (80) & 18 & (71) & 25 & (64) & 11 & (75) & 22 & (66) & 23 & (66) & 12 & (68) & 17 & (73) & 16 & (70) \\
\hline Nitzer & 3 & (82) & 8 & (81) & 14 & (79) & 11 & (75) & 20 & (68) & 12 & (75) & 10 & (70) & 11 & (70) & 9 & (72) & 19 & (71) & 3 & (72) \\
\hline ustria & 19 & (73) & 13 & (78) & 11 & (81) & 13 & (74) & 15 & (72) & 13 & (74) & 12 & (70) & 9 & (72) & 8 & (73) & 10 & (76) & 18 & (69) \\
\hline ance & 11 & (78) & 15 & (76) & 13 & (80) & 16 & (73) & 8 & (77) & 14 & (73) & 15 & (68) & 18 & (67) & 25 & (6 & 13 & (74) & 5 & (72) \\
\hline ain & 22 & (72) & 17 & (75) & 15 & (76) & 15 & (74) & 13 & (73) & 15 & (73) & 21 & (66) & 28 & (64) & 17 & $(66)$ & 21 & (69) & 21 & (67) \\
\hline aly & 21 & (73) & 22 & (71) & 20 & (72) & 10 & (75) & 6 & (79) & 16 & (72) & 14 & (68) & 22 & (66) & 22 & (66) & 18 & (72) & 19 & (69) \\
\hline uge & 30 & (63) & 23 & (71) & 17 & (74) & 19 & 165 & 19 & (70) & 17 & (72) & 26 & (65) & 21 & (66) & 19 & (66) & 24 & $(66)$ & 32 & $(60)$ \\
\hline ew & 14 & (77) & 21 & (72) & 19 & (73) & 21 & (67) & 16 & (71) & 18 & (71) & 18 & (67) & 17 & (67) & 27 & (64) & 16 & (73) & 22 & (67) \\
\hline nite & 2 & (83) & 18 & (73) & 9 & (85) & 5 & (79) & 4 & (81) & 19 & (71) & 13 & (70) & 19 & (67) & 15 & (67) & 14 & (74) & 1 & (79) \\
\hline inland & 23 & (72) & 14 & (76) & 21 & (72) & 35 & (59) & 28 & (63) & 20 & (70) & 9 & (71) & 10 & (72) & 11 & (71) & 12 & (75) & 26 & (65) \\
\hline inga & 26 & (70) & 29 & (64) & 25 & (66) & 66 & (4 & 66 & (51) & 21 & (68) & 19 & (67) & 31 & (62) & 24 & (6 & 35 & 16 & 24 & (66) \\
\hline eba & 43 & (57) & 62 & (51) & 29 & (64) & 31 & 16 & 65 & (51) & 22 & (67) & 76 & (49) & 62 & (53) & 49 & (5 & 79 & (48) & 61 & (51) \\
\hline ana & 4 & (82) & 10 & (80) & 16 & (75) & 17 & (72 & 14 & (73) & 23 & (67) & 17 & 16 & 32 & (62) & 26 & (6 & 15 & (7) & 2 & (75) \\
\hline pa & 27 & (67) & 46 & (55) & 54 & (53) & 37 & $(5$ & 41 & (57) & 24 & (67) & 53 & (5 & 60 & (53) & 41 & (58) & 6 & (56) & 25 & (66) \\
\hline ore & 34 & (61) & 34 & (62) & 31 & (63) & 26 & 16 & 17 & (71) & 25 & (6 & 34 & (6 & 37 & (61) & 32 & (6 & 7 & $(\epsilon$ & 30 & (62) \\
\hline ze & 36 & (59) & 24 & (69) & 23 & (70) & 25 & (6 & 29 & (63) & 26 & (66) & 20 & (67) & 14 & (68) & 20 & (66) & 2 & (6 & 38 & (57) \\
\hline roatia & 45 & (56) & 38 & (58) & 43 & (58) & 60 & (5 & 27 & (64) & 27 & (65) & 30 & (63) & 12 & (68) & 28 & (64) & 23 & (66) & 49 & (55) \\
\hline Ox & 38 & (59) & 33 & (62) & 30 & (63) & 22 & 16 & 23 & (65) & 28 & (64) & 28 & (64) & 15 & (67) & 16 & (66) & 20 & (69) & 31 & $(60)$ \\
\hline oland & 49 & (55) & 28 & (64) & 24 & (69) & 28 & 16 & 21 & (68) & 29 & (64) & 31 & (63) & 33 & (62) & 34 & (60) & 8 & (65) & 44 & (56) \\
\hline arke & 47 & $(5$ & 74 & (47) & 5 & (52) & 44 & (5 & 50 & (55) & 30 & (62) & 47 & (5 & 49 & (56) & 65 & (52) & 38 & (5 & 39 & (57) \\
\hline ith & 55 & (53) & 37 & (59) & 35 & (62) & 20 & 16 & 24 & (65) & 31 & (61) & 25 & (65) & 26 & (65) & 38 & (59) & 47 & (56) & 54 & (53) \\
\hline Cyp & 32 & (63) & 27 & (64) & 26 & (65) & 43 & (5 & 35 & (60) & 32 & (6 & 33 & (6 & 35 & (61) & 21 & (6 & 33 & & 33 & (59) \\
\hline ree & 31 & (63) & 36 & (60) & 38 & 0) & 47 & $(5$ & 64 & (51) & 33 & (60) & 41 & (58) & 47 & (56) & 40 & (5 & 9 & 16 & 27 & $(65)$ \\
\hline Israel & 2 & ( & 32 & 16 & 27 & & 50 & & 2 & & 34 & (6 & 36 & & 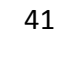 & (59) & 42 & $(5$ & 26 & D) & 4 & 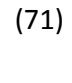 \\
\hline na & 83 & (45) & 70 & (49) & 48 & 6) & 34 & $(6$ & 34 & (60) & 35 & (60 & 49 & (55) & 42 & (58) & 53 & (54) & 39 & (58) & 92 & $(45)$ \\
\hline $\mathrm{mir}$ & 1 & ( & 59 & ( & 32 & (63) & 9 & 1. & 7 & 5) & 30 & $(\epsilon$ & 2 & ( & 7 & ) & 44 & ( & 36 & ) & 7 & (70) \\
\hline ob & 51 & (55) & 31 & (63) & 36 & 1) & 41 & $(5$ & 59 & (53) & 37 & (59) & 29 & $(6$ & 7 & (65) & 37 & (59) & 2 & & 57 & $(52)$ \\
\hline hile & 40 & (58) & 35 & (61) & 41 & (58) & 81 & (4 & 49 & (55) & 38 & (59) & 35 & $(62)$ & 36 & (61) & 31 & $(62)$ & 25 & $(65)$ & 51 & (55) \\
\hline wazilan & 85 & (44) & 50 & (54) & 34 & (62) & 30 & (62 & 53 & (54) & 39 & (59) & 103 & $(42)$ & 84 & (48) & 85 & (48) & 86 & (46) & 96 & (44) \\
\hline lam & 1 & (83) & 16 & (76) & 50 & 5) & 32 & 16 & 11 & (75) & 40 & (58) & 43 & (57) & 58 & (53) & 70 & (51) & 68 & 2) & 7 & $(72)$ \\
\hline ongo, Rep. & 67 & (49) & 30 & (63) & 33 & (62) & 42 & (57) & 44 & (56) & 41 & (58) & 24 & (66) & 20 & (67) & 51 & (55) & 48 & (56) & 100 & (43) \\
\hline elarus & 81 & (46) & 00 & (41) & 6 & (50) & 29 & (62) & 37 & (59) & 42 & (57) & 108 & (42) & 74 & (50) & 79 & (50) & 58 & (5 & 60 & (51) \\
\hline uisury & 42 & (58) & 26 & (65) & 3 & (59) & 45 & (5 & 55 & (54) & 43 & (57) & 27 & (64) & 24 & (66) & 33 & (61) & 31 & (62) & 46 & (55) \\
\hline stonia & 37 & (59) & 40 & (57) & 69 & (48) & 99 & $(4$ & 88 & (45) & 44 & (56) & 46 & (56) & 39 & (60) & 30 & (63) & 41 & (57) & 45 & (55) \\
\hline Maldive & 72 & (48) & 52 & (54) & 66 & (49) & 55 & (52) & 40 & (57) & 45 & (56) & 23 & (66) & 25 & (65) & 66 & (52) & 99 & (43) & 87 & (46) \\
\hline Malta & 44 & (57) & 25 & (67) & 28 & (65) & 33 & (61) & 45 & (56) & 46 & (56) & 32 & (62) & 29 & (64) & 23 & (65) & 30 & (63) & 63 & (50) \\
\hline Jbania & 78 & (46) & 83 & (45) & 4 & (57) & 38 & $(5$ & 38 & (58) & 47 & (56) & 79 & (48) & 73 & (51) & 69 & (52) & 51 & (55) & 72 & (49) \\
\hline lovak Rep & 50 & (55) & 41 & (57) & 45 & (57) & 63 & $(5$ & 69 & (50) & 48 & (56) & 38 & (59) & 30 & (63) & 29 & (64) & 32 & (61) & 40 & (57) \\
\hline hailand & 71 & (48) & 49 & (54) & 37 & (60) & 27 & (64) & 30 & (63) & 49 & (56) & 51 & (55) & 44 & (56) & 55 & (54) & 70 & (51) & 68 & (50) \\
\hline Bahamas, The & 28 & (64) & 20 & (72) & 22 & (72) & 23 & (66) & 33 & (60) & 50 & (55) & 39 & (59) & 34 & (62) & 14 & (67) & 34 & (61) & 50 & (55) \\
\hline omani & 69 & (48) & 39 & (57) & 46 & (57) & 24 & (65) & 26 & (64) & 51 & (54) & 57 & (53) & 43 & (57) & 46 & (57) & 52 & (55) & 69 & (49) \\
\hline Didát & 70 & $(48$ & 71 & (49) & 64 & (50) & 59 & $(5$ & 52 & (54) & 52 & (54) & 64 & (52) & 70 & (51) & 67 & (52) & 72 & $(50)$ & 66 & $(50)$ \\
\hline Iurkmenistan & 94 & $(42)$ & 82 & (45) & b/ & (52) & 46 & (55) & 70 & (49) & 53 & (54) & 128 & (33) & 115 & (39) & 98 & (44) & 107 & (38) & 109 & (41) \\
\hline Tunisia & 86 & (44) & 45 & (55) & 42 & (58) & 36 & (59) & 108 & (41) & 54 & (52) & 88 & (46) & 77 & (49) & 68 & (52) & 103 & $(42)$ & 108 & (42) \\
\hline Colombia & 82 & (45) & 63 & (51) & 49 & (56) & 48 & (54) & 57 & (53) & 55 & $(52)$ & 48 & (55) & 52 & (55) & 54 & (54) & 50 & (55) & 88 & $(46)$ \\
\hline
\end{tabular}


Table A2. Country ranking and index (2000-2010). (Cont.)

\begin{tabular}{|c|c|c|c|c|c|c|c|c|c|c|c|c|c|c|c|c|c|c|c|c|c|c|}
\hline y & 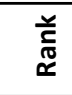 & চ্ণ & 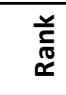 & ઠ્' & 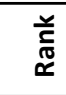 & ธ్రి & 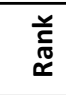 & ஜ్ & 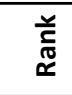 & ষ্ণ & $\begin{array}{l}\text { 弟 } \\
\text { 『̋ }\end{array}$ & ํㅗㅇ & 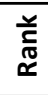 & ஜ્ટ & $\begin{array}{l}\text { 兰 } \\
\text { 疍 }\end{array}$ & ఫ్ర & 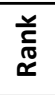 & : & 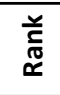 & : & 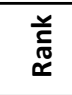 & 워 \\
\hline & 93 & $(42)$ & 3 & (38) & 78 & (45) & 56 & (52 & 67 & (50 & 56 & (52) & 70 & (50) & 6 & (5 & 3 & ( & 8 & (43) & 8 & 3) \\
\hline \multicolumn{23}{|l|}{ ussian } \\
\hline deration & 52 & 4) & 75 & 7) & 97 & (41) & 77 & (48) & 83 & (46) & 57 & (52) & 44 & (57) & 55 & (55) & 78 & (50) & 67 & (52) & 37 & (57) \\
\hline & 60 & (51) & 55 & (53) & 60 & (51) & 51 & (53) & 46 & (56) & 58 & (52) & 71 & ( & 63 & ) & 59 & $(5$ & 3 & (56) & 41 & (57) \\
\hline 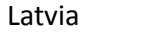 & 46 & (55) & 51 & (54) & 53 & (53) & 53 & (52) & 43 & $(57$ & 59 & (51) & 42 & (58) & 46 & $(5$ & 50 & (56 & 40 & (58) & 43 & (56) \\
\hline & 79 & (46) & 64 & (5 & 94 & (42) & 125 & (36) & 134 & (30) & 60 & (51 & 66 & (52) & 61 & (53) & 73 & (50) & 66 & (52) & 1 & (49) \\
\hline ts & 75 & (47) & 60 & (5 & 61 & (5) & 52 & (53) & 63 & (52) & 61 & ( & 74 & (50) & 105 & ( & 95 & (4 & 5 & (L & 2 & (5 \\
\hline ulgaria & 87 & (44) & 88 & (44) & 80 & (45) & 54 & (52) & 31 & (61) & 62 & 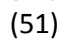 & 40 & (59) & 38 & 1 & 35 & (59) & 2 & (57) & 80 & (47) \\
\hline & 48 & (55) & 48 & (55) & 75 & (46) & 87 & (46) & 90 & (45) & 63 & (51) & 59 & (53) & 45 & (56) & 60 & (53) & 54 & (54) & 52 & (54) \\
\hline atar & 18 & (74) & 43 & (56) & 47 & (56) & 111 & (40) & 117 & (37) & 64 & (51) & 55 & (54) & 71 & (51) & 39 & (59) & 59 & (54) & 13 & (71) \\
\hline hrain & 33 & (62) & 42 & (5 & 58 & (52) & 80 & (47) & 106 & (41) & 65 & (5. & 63 & $(52$ & 64 & (5 & 36 & (59) & 5 & (56) & 5 & (58) \\
\hline r. & 61 & (51) & 54 & (53) & 63 & (50) & 86 & (46) & 82 & (46) & 66 & (50) & 45 & (57) & 51 & (55) & 43 & (57) & 49 & (55) & 55 & (52) \\
\hline rmenia & 114 & (37) & 101 & (41) & 81 & (44) & 49 & (54) & 102 & (42) & 67 & (50) & 68 & (51) & 67 & (52) & 72 & (50) & 76 & (49) & 102 & (43) \\
\hline kraine & 95 & (42) & 93 & (43) & 108 & (39) & 64 & (50) & 95 & (44) & 68 & (50) & 78 & (49) & 75 & (50) & 76 & (50) & 89 & (45) & 91 & (45) \\
\hline Zambia & 121 & (35) & 77 & (47) & 87 & (43) & 57 & (52) & 60 & (53) & 69 & (50) & 83 & (48) & 89 & (46) & 96 & (45) & 83 & (46) & 126 & (36) \\
\hline
\end{tabular}

Dominican

$\begin{array}{lllllllllllllllllllllll}\text { Republic } & 77 & (47) & 4 & (45) & 82 & (44) & 107 & (41) & 104 & (42) & 70 & (50) & 67 & (51) & 68 & (52) & 57 & (53) & 84 & (46) & 70 & (49)\end{array}$ $\begin{array}{lllllllllllllllllllllll}\text { Cambodia } & 127 & (33) & 103 & (41) & 113 & (38) & 75 & (48) & 101 & (42) & 71 & (49) & 91 & (45) & 72 & (51) & 92 & (46) & 81 & (47) & 129 & (36)\end{array}$ $\begin{array}{lllllllllllllllllllllll}\text { Gabon } & 59 & (51) & 87 & (44) & 102 & (40) & 109 & (41) & 36 & (60) & 72 & (49) & 89 & (46) & 102 & (44) & 90 & (46) & 85 & (46) & 47 & (55)\end{array}$ $\begin{array}{llllllllllllllllllllllll}\text { Costa Rica } & 68 & (49) & 61 & (51) & 83 & (44) & 69 & (49) & 86 & (46) & 73 & (49) & 58 & (53) & 66 & (52) & 48 & (56) & 60 & (54) & 74 & (49)\end{array}$ $\begin{array}{lllllllllllllllllllllll}\text { Azerbaijan } & 118 & (36) & 91 & (44) & 91 & (43) & 119 & (37) & 120 & (37) & 74 & (49) & 65 & (52) & 86 & (47) & 86 & (48) & 90 & (45) & 77 & (48)\end{array}$ $\begin{array}{lllllllllllllllllllllll}\text { Tanzania } & 124 & (34) & 108 & (40) & 71 & (48) & 92 & (44) & 92 & (44) & 75 & (48) & 97 & (44) & 98 & (44) & 113 & (39) & 106 & (40) & 132 & (36)\end{array}$ $\begin{array}{llllllllllllllllllllllll}\text { El Salvador } & 104 & (39) & 79 & (46) & 100 & (40) & 67 & (49) & 93 & (44) & 76 & (48) & 54 & (54) & 59 & (53) & 58 & (53) & 74 & (49) & 107 & (42)\end{array}$ $\begin{array}{lllllllllllllllllllllll}\text { Honduras } & 115 & (36) & 86 & (45) & 104 & \text { (40) } & 115 & \text { (39) } & 123 & \text { (36) } & 77 & \text { (48) } & 60 & \text { (53) } & 53 & \text { (55) } & 62 & (53) & 69 & (52) & 116 & \text { (39) }\end{array}$ Venezuela,

$\begin{array}{lllllllllllllllllllllll}\mathrm{RB} & 62 & (51) & 58 & (52) & 95 & (42) & 134 & (32) & 137 & (27) & 78 & (47) & 84 & (48) & 85 & (47) & 80 & (49) & 78 & (48) & 56 & (52)\end{array}$ $\begin{array}{lllllllllllllllllllllll}\text { Georgia } & 99 & (41) & 120 & (37) & 126 & (32) & 90 & (45) & 75 & (47) & 79 & (47) & 50 & (55) & 54 & (55) & 64 & (52) & 55 & (54) & 85 & (46)\end{array}$ $\begin{array}{lllllllllllllllllllllll}\text { Argentina } & 56 & (53) & 53 & (53) & 72 & (47) & 97 & (43) & 84 & (46) & 80 & (47) & 56 & (54) & 80 & (49) & 52 & (54) & 65 & (52) & 53 & (54)\end{array}$ $\begin{array}{lllllllllllllllllllllll}\text { Vietnam } & 129 & (32) & 90 & (44) & 77 & (46) & 85 & (46) & 62 & (52) & 81 & (47) & 80 & (48) & 56 & (54) & 74 & (50) & 73 & (50) & 125 & (36)\end{array}$ Macedonia,

$\begin{array}{lllllllllllllllllllllll}\text { FYR } & 66 & (49) & 56 & (53) & 40 & (59) & 40 & (58) & 51 & (54) & 82 & (46) & 52 & (54) & 50 & (55) & 61 & (53) & 57 & (54) & 59 & (51)\end{array}$ $\begin{array}{lllllllllllllllllllllll}\text { Saudi Arabia } & 35 & (60) & 94 & (43) & 68 & (48) & 73 & (48) & 100 & (42) & 83 & (46) & 87 & (46) & 95 & (44) & 84 & (48) & 63 & (53) & 34 & (58)\end{array}$ $\begin{array}{lllllllllllllllllllllll}\text { Chad } & 112 & (37) & 110 & (39) & 92 & (42) & 79 & (47) & 81 & (46) & 84 & (46) & 127 & \text { (34) } & 129 & \text { (32) } & 131 & \text { (33) } & 118 & \text { (35) } & 118 & \text { (39) }\end{array}$ $\begin{array}{lllllllllllllllllllllll}\text { Belize } & 57 & (52) & 44 & (56) & 119 & (35) & 108 & (41) & 68 & (50) & 85 & (45) & 37 & (60) & 40 & (59) & 47 & (56) & 64 & (52) & 65 & (50)\end{array}$ $\begin{array}{llllllllllllllllllllllll}\text { China } & 98 & (42) & 66 & (50) & 51 & (54) & 58 & (52) & 76 & (47) & 86 & (45) & 99 & (43) & 97 & (44) & 101 & (44) & 91 & (45) & 67 & (50)\end{array}$ $\begin{array}{lllllllllllllllllllllll}\text { Malawi } & 139 & (23) & 135 & (25) & 133 & (27) & 133 & (33) & 107 & (41) & 87 & (45) & 93 & (44) & 104 & (43) & 112 & \text { (39) } & 133 & (31) & 139 & (28)\end{array}$ $\begin{array}{lllllllllllllllllllllll}\text { Indonesia } & 76 & (47) & 104 & (41) & 96 & (41) & 68 & (49) & 61 & (52) & 88 & (45) & 86 & (47) & 65 & (52) & 87 & (47) & 71 & (51) & 78 & (47)\end{array}$ $\begin{array}{lllllllllllllllllllllll}\text { Philippines } & 101 & (41) & 122 & (36) & 86 & (44) & 70 & (49) & 48 & (55) & 89 & (45) & 69 & (51) & 82 & (48) & 106 & (41) & 96 & (43) & 83 & (46)\end{array}$ $\begin{array}{lllllllllllllllllllllll}\text { Mauritius } & 54 & (53) & 68 & (49) & 56 & (52) & 84 & (46) & 73 & (48) & 90 & (45) & 82 & (48) & 79 & (49) & 63 & (53) & 56 & (54) & 48 & (55)\end{array}$ $\begin{array}{lllllllllllllllllllllll}\text { Burkina Faso } & 65 & (49) & 115 & (38) & 74 & (47) & 74 & (48) & 71 & (49) & 91 & (44) & 117 & (39) & 109 & (42) & 117 & (37) & 53 & (55) & 75 & (48)\end{array}$ $\begin{array}{lllllllllllllllllllllll}\text { South Africa } & 41 & (58) & 76 & (47) & 70 & (48) & 72 & (49) & 96 & (43) & 92 & (44) & 90 & (45) & 83 & (48) & 77 & (50) & 75 & (49) & 42 & (56)\end{array}$

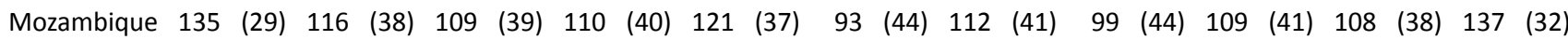
$\begin{array}{lllllllllllllllllllllll}\text { Mongolia } & 123 & (35) & 109 & (39) & 111 & (39) & 94 & (44) & 126 & (35) & 94 & (44) & 85 & (47) & 87 & (46) & 91 & (46) & 97 & (43) & 133 & (36)\end{array}$ $\begin{array}{lllllllllllllllllllllll}\text { Namibia } & 90 & (44) & 97 & (42) & 101 & (40) & 103 & (42) & 72 & (48) & 95 & (44) & 72 & (50) & 90 & (46) & 99 & (44) & 119 & (35) & 79 & (47)\end{array}$ $\begin{array}{lllllllllllllllllllllll}\text { Malaysia } & 39 & (59) & 57 & (52) & 89 & (43) & 93 & (44) & 103 & (42) & 96 & (43) & 100 & (43) & 81 & (49) & 71 & (51) & 82 & (47) & 36 & (58)\end{array}$ $\begin{array}{lllllllllllllllllllllll}\text { Guyana } & 108 & (38) & 80 & (46) & 116 & (38) & 140 & (23) & 124 & (35) & 97 & (43) & 61 & (53) & 69 & (51) & 82 & (49) & 94 & (43) & 120 & (38)\end{array}$ $\begin{array}{lllllllllllllllllllllll}\text { Kuwait } & 24 & (71) & 69 & (49) & 79 & (45) & 76 & (48) & 116 & (38) & 98 & (43) & 139 & (30) & 139 & (25) & 81 & (49) & 100 & (43) & 23 & (67)\end{array}$ $\begin{array}{lllllllllllllllllllllll}\text { Oman } & 29 & (64) & 47 & (55) & 59 & (52) & 61 & (51) & 122 & (36) & 99 & (43) & 95 & (44) & 96 & (44) & 56 & (53) & 44 & (56) & 28 & (63)\end{array}$ $\begin{array}{lllllllllllllllllllllll}\text { Uruguay } & 73 & (48) & 65 & (50) & 73 & (47) & 71 & (49) & 128 & (34) & 100 & (42) & 73 & (50) & 48 & (56) & 45 & (57) & 37 & (59) & 64 & (50)\end{array}$

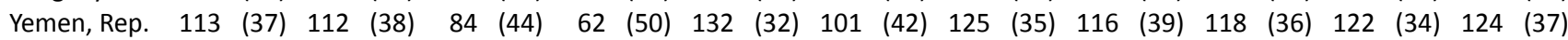
$\begin{array}{lllllllllllllllllllllll}\text { Paraguay } & 103 & (39) & 102 & (41) & 99 & (41) & 106 & (41) & 112 & (39) & 102 & (42) & 107 & (42) & 92 & (45) & 93 & (45) & 93 & (44) & 97 & (44)\end{array}$

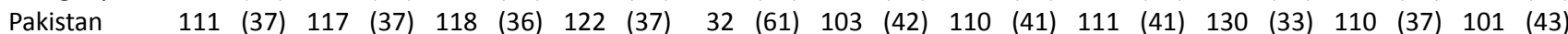
$\begin{array}{lllllllllllllllllllllll}\text { Cote d'Ivoire } & 63 & (50) & 95 & (42) & 88 & (43) & 124 & (36) & 80 & (46) & 104 & (41) & 113 & (40) & 120 & (37) & 114 & (38) & 123 & (33) & 86 & (46)\end{array}$ $\begin{array}{lllllllllllllllllllllll}\text { Nigeria } & 97 & (42) & 119 & (37) & 117 & \text { (37) } & 114 & (39) & 54 & (54) & 105 & (41) & 101 & \text { (43) } & 119 & \text { (37) } & 105 & (42) & 92 & (44) & 81 & (47)\end{array}$ $\begin{array}{lllllllllllllllllllllll}\text { Moldova } & 116 & (36) & 118 & (37) & 110 & (39) & 100 & (42) & 105 & (42) & 106 & (41) & 111 & (41) & 100 & (44) & 97 & (45) & 87 & (46) & 106 & (42)\end{array}$ $\begin{array}{lllllllllllllllllllllll}\text { Uzbekistan } & 125 & \text { (34) } & 126 & \text { (34) } & 135 & \text { (25) } & 78 & (47) & 94 & \text { (44) } & 107 & \text { (41) } & 122 & \text { (35) } 117 & \text { (38) } & 107 & \text { (41) } & 101 & (42) & 112 & \text { (40) }\end{array}$

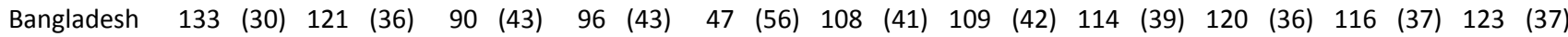
$\begin{array}{lllllllllllllllllllllll}\text { Benin } & 64 & (49) & 73 & (47) & 52 & (54) & 95 & (43) & 89 & (45) & 109 & (41) & 96 & (44) & 101 & (44) & 108 & (41) & 61 & (53) & 90 & (45)\end{array}$ $\begin{array}{lllllllllllllllllllllll}\text { Guatemala } & 80 & (46) & 72 & (48) & 67 & (49) & 65 & (50) & 91 & (45) & 110 & (41) & 94 & (44) & 107 & (42) & 102 & (42) & 88 & (45) & 76 & (48)\end{array}$ 
Table A2. Country ranking and index (2000-2010). (Cont.)

\begin{tabular}{|c|c|c|c|c|c|c|c|c|c|c|c|c|c|c|c|c|c|c|c|c|c|c|}
\hline u & 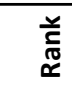 & ষ্ণ & 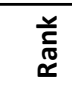 & ઠ્ડ & 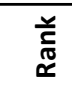 & ণั่ & 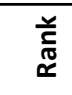 & ֻัญ & 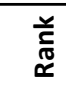 & ষ্ণ & 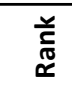 & นั & 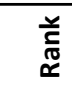 & ๕ั & 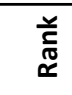 & : & 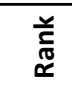 & : & $\begin{array}{l}\text { 弟 } \\
\text { ॠ }\end{array}$ & ஜ্ণ & 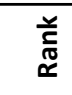 & 울 \\
\hline \multicolumn{23}{|l|}{ Papua New } \\
\hline uinea & 89 & (44) & 99 & (41) & 93 & $(42)$ & 83 & (46) & 87 & (45) & 111 & (40) & 134 & (32) & 130 & (32) & 125 & (35) & 127 & (32) & 110 & (41) \\
\hline cara & 107 & (39) & 81 & (45) & 114 & (38) & 112 & (40) & 99 & 3) & 12 & (39) & 75 & (49) & 78 & (49) & 89 & (47) & 105 & (41) & 119 & (39) \\
\hline dia & 96 & (42) & 114 & (38) & 105 & (40) & 91 & (45) & 39 & 8) & 13 & (39) & 115 & (39) & 124 & (34) & 127 & (34) & 114 & (37) & 84 & (46) \\
\hline \multicolumn{23}{|l|}{ Iran, } \\
\hline Islami & 58 & (52) & 130 & (30) & 128 & (31) & 121 & (37) & 85 & (46) & 114 & (39) & 121 & (36) & 132 & (31) & 126 & (35) & 129 & (32) & 58 & (51) \\
\hline mbabwe & 110 & (37) & 96 & (42) & 98 & (41) & 120 & (37) & 115 & 38) & 115 & (39) & 105 & $(42)$ & 110 & (41) & 122 & (36) & 120 & (34) & 138 & (31) \\
\hline rdan & 88 & (44) & 78 & (46) & 107 & (40) & 116 & (39) & 127 & 34) & 116 & (39) & 81 & (48) & 88 & (46) & 75 & (50) & 80 & (47) & 93 & (44) \\
\hline & 84 & (45) & 92 & (43) & 76 & (46) & 89 & (45) & 118 & (37) & 117 & (38) & 126 & (34) & 135 & (29) & 129 & (34) & 132 & (31) & 99 & (43) \\
\hline \multicolumn{23}{|c|}{ 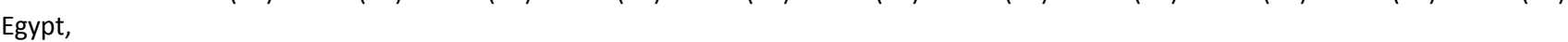 } \\
\hline rab Rep. & 120 & (36) & 105 & (41) & 112 & (39) & 135 & (31) & 139 & (27) & 118 & (38) & 118 & (38) & 103 & (44) & 104 & (42) & 111 & (37) & 121 & (38) \\
\hline . & 131 & (32) & 85 & (45) & 85 & (44) & 82 & (46) & 97 & (43) & 119 & (37) & 102 & (42) & 108 & (42) & 94 & (45) & 112 & (37) & 134 & (35) \\
\hline & 1 & (43) & 107 & (40) & 106 & (40) & 88 & (45) & 78 & (46) & 120 & (36) & 114 & (40) & 118 & (38) & 110 & (40) & 113 & (37) & 89 & (4 \\
\hline ajikista & 136 & (28) & 39 & (23) & 134 & (26) & 128 & (35) & 111 & (40) & 121 & (36) & 106 & (42) & 106 & (42) & 119 & (36) & 117 & (35) & 128 & (36) \\
\hline eru & 92 & (43) & 98 & (42) & 120 & (35) & 130 & (34) & 131 & (32) & 122 & (36) & 77 & (49) & 91 & (45) & 88 & (47) & 77 & (48) & 73 & (49) \\
\hline \multicolumn{23}{|l|}{ yrgyz } \\
\hline epublic & 2 & 31) & 28 & ) & 124 & (32) & 98 & (43) & 79 & (46) & 12 & (36) & 104 & (42) & 112 & (41) & 115 & (38) & 115 & (37) & L & (3 \\
\hline & 0 & 2) & 31 & (30) & 121 & (35) & 118 & (38) & 114 & 8) & 124 & (35) & 119 & (37) & 122 & (35) & 128 & (34) & 09 & (38) & 27 & (3 \\
\hline & 117 & (36) & 124 & (34) & 127 & (31) & 137 & (30) & 129 & (33) & 125 & (35) & 116 & (39) & 121 & (37) & 116 & (38) & 121 & (34) & 130 & (36) \\
\hline oli & 102 & (41) & 89 & (44) & 129 & (30) & 127 & (35) & 135 & (29) & 126 & (35) & 92 & (45) & 94 & (45) & 100 & (44) & 102 & (42) & 95 & (44) \\
\hline$p$ & 126 & (33) & 125 & (34) & 125 & (32) & 105 & (41) & 58 & (53) & 127 & (34) & 137 & (31) & 140 & (23) & 140 & (21) & 139 & (24) & 117 & (39) \\
\hline enva & 106 & (39) & 123 & (35) & 123 & (33) & 129 & (35) & 56 & (54) & 128 & (33) & 131 & (32) & 126 & (33) & 137 & (30) & 125 & (33) & 104 & (43) \\
\hline- & 128 & (33) & 132 & (28) & 131 & (29) & 131 & (33) & 125 & (35) & 129 & (33) & 120 & (37) & 123 & (35) & 133 & (32) & 136 & (27) & 122 & (37) \\
\hline & 122 & (35) & 129 & (31) & 122 & (34) & 102 & $(42)$ & 109 & (40) & 130 & (31) & 133 & (32) & 131 & (31) & 136 & (30) & 134 & (30) & 115 & (39) \\
\hline had & 140 & (23) & 141 & (20) & 139 & $(21)$ & 126 & (36) & 113 & $(3$ & ( & (31) & 129 & (33) & 113 & (40) & 123 & (36) & 137 & (24) & 142 & (22) \\
\hline Igeria & 74 & (48) & 106 & (40) & 103 & (40) & 101 & (42) & 138 & (27) & 132 & (31) & 135 & (32) & 137 & (29) & 124 & (36) & 128 & (32) & 82 & (46) \\
\hline \multicolumn{23}{|l|}{ Syrian Aral } \\
\hline epublic & 100 & (41) & 11 & (38) & 115 & (38) & 113 & (40) & 133 & (31) & 133 & (31) & 123 & (35) & 125 & (34) & 121 & (36) & 130 & (31) & 103 & (43) \\
\hline thi & 141 & (23) & 138 & (23) & 132 & (29) & 136 & (30) & 98 & (43) & 134 & (30) & 132 & (32) & 134 & (30) & 139 & (25) & 138 & (24) & 135 & (35) \\
\hline Idan & 109 & (38) & 134 & (26) & 137 & (24) & 141 & (23) & 136 & (28) & 135 & (30) & 130 & (33) & 127 & (33) & 132 & (32) & 135 & (28) & 113 & (40) \\
\hline egal & 105 & (39) & 133 & (26) & 138 & (22) & 138 & (26) & 74 & (48) & 136 & (29) & 140 & (29) & 133 & (31) & 134 & (32) & 124 & (33) & 94 & (44) \\
\hline hana & 134 & (30) & 140 & (23) & 140 & (19) & 117 & (38) & 130 & (33) & 137 & (28) & 136 & (32) & 136 & (29) & 138 & (27) & 140 & (22) & 114 & (39) \\
\hline raq & 53 & (54) & 67 & (49) & 62 & (50) & 104 & (41) & 140 & (24) & 138 & (27) & 124 & (35) & 128 & (32) & 111 & (39) & 104 & (42) & 105 & (43) \\
\hline & 119 & (36) & 136 & (24) & 130 & (30) & 132 & (33) & 119 & (37) & 139 & (25) & 138 & (31) & 138 & (28) & 135 & (31) & 131 & (31) & 136 & (34) \\
\hline ( & 142 & (18) & 137 & (23) & 136 & (25) & 123 & (37) & 110 & (40) & 140 & (25) & 142 & (9) & 142 & (6) & 142 & (12) & 141 & (21) & 141 & (25) \\
\hline Liberia & 138 & (24) & 127 & (34) & 141 & (14) & 139 & (24) & 141 & (14) & 141 & (20) & 98 & (43) & 93 & (45) & 103 & (42) & 126 & (32) & 140 & (27) \\
\hline Cuba & 137 & (27) & 142 & (12) & 142 & (1) & 142 & (17) & 142 & (13) & 142 & (7) & 141 & (9) & 141 & (7) & 141 & (19) & 142 & (5) & 111 & (41) \\
\hline
\end{tabular}

Note: The rank details the country rank of each country in that year according to the index value in parentheses. Countries are ranked according to their score in 2005. 


\section{MIMIC Model and Factor Score for Latent Variable}

Jöreskog and Goldberger (1975) developed the formal specification of the approach for one latent variable. It encompasses a system of two equations: first showing how the unobservable variable in the measurement equation model determines the examined endogenous variables; and second how the latent variable and its causes interact. The model is formally characterized in the following way. The independent indicators are denoted by $y_{i}(i=1, \ldots, m)$ and $\eta$ is the latent variable (i.e. human trafficking) such that:

$$
y_{i}=\beta_{i} \eta+\varepsilon_{i}
$$

The $1 \times m$ parameter vector $\beta_{i}=\left\{\beta_{1}, \beta_{2} \ldots, \beta_{m}\right\}^{\prime}$ embodies the coefficients which indicate the estimated alteration in the respective indicators after a one unit change in the latent variable. The error terms $\varepsilon_{i}, i=1, \ldots, m$ have mean zero and covariance matrix $\theta_{\varepsilon}$. The correlation across indicators is exclusively determined by the common factor $\eta$. Equation (1) is a confirmatory factor analysis model for the observable indicators $y=\left(y_{1}, y_{2}, \ldots, y_{m}\right)^{\prime}$ including the common factor $\eta$ and the unique factor $\varepsilon_{i}$. In the covariance matrix $\theta_{\varepsilon}$, the diagonal elements are represented in the $1 \times m$ vector $\tau$.

Moreover, the latent unobservable variable $\eta$ can be linearly decomposed in the following way:

$$
\eta=\alpha^{\prime} x+\omega,
$$

where $\alpha=\left(\alpha_{1}, \alpha_{2}, \ldots, \alpha_{s}\right)^{\prime}$ are parameters, $\boldsymbol{x}=\left(x_{1}, x_{2}, \ldots, x_{s}\right)^{\prime}$ is the vector of observable exogenous causal variables and a stochastic error term $\omega$. The model described in equation (1) is also called a measurement model of the observed endogenous indicators determined by the latent variable. Any correlation between the elements of $y$ results from the association with $\eta$. The indicators are assumed to be partially independent between all indicator pairs $i$ and $j$ setting all diagonal elements of $\theta_{\varepsilon}$ equal to zero. The second component of the model is a structural equation (2) that characterizes the relationship between the latent variable and its causes.

The structural parameters $\alpha$ are not directly estimable due to the latent nature of the objective variable. Equation (1) is inserted in equation (2) in order to derive the reduced form which connects the observable variables from (1) and (2) via the equation

$$
\gamma=\Pi^{\prime} x+y .
$$

This is a multivariate regression model which includes the endogenous indicators $\boldsymbol{y}=\left(y_{1}, \ldots, y_{n}\right)^{\prime}$ and the exogenous causes $\boldsymbol{x}=\left(x_{1}, x_{2}, \ldots, x_{s}\right)^{\prime}$ of the latent factor $\eta$. The reduced form coefficient matrix has the rank $(m \times s)=1$ and is given by $\Pi=\alpha \beta^{\prime}$. The $(1 \times m)$ reduced form disturbance vector reads as $\gamma=\beta \omega+\varepsilon$ and has the error covariance matrix:

$$
\theta_{\omega}=\mathrm{E}\left[(\beta \omega+\varepsilon)(\beta \omega+\varepsilon)^{\prime}\right]=\sigma_{\omega}^{2} \beta \beta^{\prime}+\theta_{\varepsilon} .
$$

The variance $\left(\sigma_{\omega}^{2}\right)$ of the stochastic error term has the characteristic structure of the covariance matrix of a factor analysis model. This error covariance matrix is constrained similarly to $\Pi$ because it is the sum of a one-rank matrix and a diagonal matrix. Therefore one of the elements of the factor loading vector $\beta$ has to be constrained in order to identify the model (Bollen, 1989). ${ }^{24}$ The choice of which indicator is normalized determines the scale of the latent variable but it does not affect the results of the measurement. We follow the literature and use the indicator with the largest factor loading (Bollen, 1989).

Accordingly, the estimation procedure and the identification of the model are derived by relations of the observable data, $z=\left(y^{\prime} x^{\prime}\right)^{\prime}$. The $(m+s) \times(m+s)$ covariance of the underlying model defined by equations (1) and (2) shows the relationship in terms of their respective covariance:

$$
\Sigma(\varphi)\left[\begin{array}{cc}
\beta\left(a^{\prime} \Phi_{x} \alpha+\sigma_{\omega}^{2}\right) \beta^{\prime}+\theta_{\varepsilon} & \beta \alpha^{\prime} \Phi_{x} \\
\Phi_{x} a^{\prime} \beta & \Phi_{x}
\end{array}\right] .
$$

Where $\varphi$ is the vector of independent but correlated parameters $\beta, a, \theta_{\varepsilon}$ and $\sigma_{\omega}^{2}$. The elements on the main-diagonal are $\mathrm{E}\left[y y^{\prime}\right]=\beta\left(a^{\prime} \Phi_{x} \alpha+\sigma_{\omega}^{2}\right) \beta^{\prime}+\theta_{\varepsilon}$ and $\mathrm{E}\left[x x^{\prime}\right]=\Phi_{x}$ and the off-diagonal components are $\mathrm{E}\left[x y^{\prime}\right]=\beta a^{\prime} \mathrm{E}\left[x x^{\prime}\right]$. Applying this information for the population, parameters are derived resulting in an estimate of the best approximation of the sample covariance matrix of the observed causes and indicators, $\hat{\Sigma}=\Sigma(\hat{\varphi})$. This pattern is driven by the unobservable variable.

Given (5), identification depends on the information in the matrix and whether it is sufficient to provide a unique set of values in $\varphi$. The set of mean parameters will then be identified if $q-p \geq 0$, with $q=m s$ observable moments in terms of structural parameters and $p=m+s$, which is shaped by the off-diagonal elements. If this condition holds, the remaining parameters on the diagonal will be identified. In combination, this implies that the necessary condition for identification

\footnotetext{
${ }^{24}$ Following the literature (e.g. Buehn \& Farzanegan, 2012; Dreher, Kotsogiannis, \& McCorriston, 2007), this approach is used here: one of the coefficients of the coefficient vector $\beta$ is fixed to an a priori value, such that the unit of measurement for the unobserved term is normalized relative to one of the indicator variables. Another possibility is applied mainly in factor analysis where the latent variable is standardized to have unit variance (e.g. Di Tommaso, Raiser, \& Weeks, 2007).
} 
of all parameters is given by:

$$
p \leq \frac{1}{2}(m+s)(m+s+1) .
$$

Estimation of $\Sigma(\varphi), \hat{\Sigma}=\Sigma(\hat{\varphi})$ is obtained if the parameter and covariance values are chosen in such a way that the difference between the estimate and the true sample covariance $\mathbf{S}$ of the causes and indicators is minimized using the following objective function:

$$
\mathrm{F}=\ln |\Sigma(\varphi)|+\operatorname{tr}\left[S \Sigma^{-1}(\hat{\Sigma})\right]-\ln |S|-(m+s),{ }^{25}
$$

which is a likelihood function assuming a multivariate, normal distribution. The sufficient rule for the MIMIC model to be identified is $m \geq 2$ and $s \geq 1$ (Bollen 1989: 331). Perfect fit would be achieved if the true sample covariance were equal to the estimated covariance, $\boldsymbol{S}=\Sigma(\hat{\varphi})$. This is evaluated using several indices specified below.

After identification of the relationship between the variables and the estimation of the parameters, the latent scores of $\eta$ for each country can be specified assigning factor scores using the mean vector and variance matrix of the fitted model. This method was suggested by Jöreskog (2000) and uses more structural information than a simple linear application. ${ }^{26}$ For this reason the factor score is used for the generation of the final country ranking. The factor score for the latent variable is generated in the following way:

$$
\tilde{\eta}=\hat{\Sigma}_{z \eta}^{\prime} \hat{\Sigma}_{z z} \hat{\mu}_{z}+\hat{\mu}_{\eta}
$$

with $z=\left(y^{\prime} x^{\prime}\right)^{\prime}$ the vector of all observable causes and indicators from equation $(3), Z=\left(z^{\prime} \eta^{\prime}\right)^{\prime}$ the vector of all variables of the model, $\hat{\mu}_{z}=\hat{\mu}_{z} \hat{\mu}_{e} t a$ is the fitted mean of $Z$ and

$$
\hat{\Sigma}_{\mathrm{z}}=\left(\begin{array}{ll}
\hat{\Sigma}_{z z} & \hat{\Sigma}_{z \eta} \\
\hat{\Sigma}_{z \eta}^{\prime} & \hat{\Sigma}_{\eta \eta}
\end{array}\right)
$$

is the fitted variance. Thus, the factor score is the fitted mean prediction of the latent variable, similar to prediction of the dependent variable in regression models and weighted by minimizing the objective function (7). The score of the latent variable is subsequently obtained by implementing these weights, the estimated coefficients of the measurement and the structural model in equation (8). Finally, the model is applied to measure the extent of human trafficking in destination countries. The graphic representation is a path diagram. The respective path diagram of the MIMIC model of human trafficking can be found in the article.

\section{References}

Alesina, A., Devleeschauwer, A., Easterly, W., Kurlat, S., \& Wacziarg, R. (2003). Fractionalization. Journal of Economic Growth, 8(2), 155-194.

Baraldis, A. N., \& Enders, C. K. (2010). An introduction to modern missing data analyses. Journal of School Psychology, 48, 5-37.

Bollen, K. A. (1989). Structural equations with latent variables. New Jersey: John Wiley \& Sons.

Buehn, A., \& Farzanegan, M. R. (2012). Smuggling around the world: Evidence from a structural equation model. Applied Economics, 44, 3047-3064.

Cho, S. Y., Dreher, A., \& Neumayer, E. (2014). The determinants of anti-trafficking policies: Evidence from a new index. Scandinavian Journal of Economics, 116(2), 429-454.

Di Tommaso, M., Raiser, M., \& Weeks, M. (2007). Home grown or imported? Initial conditions, external anchors and the determinants of institutional reform in the transition economies. The Economic Journal, 117, 858-881.

Dreher, A., Kotsogiannis, C., \& McCorriston, S. (2007). Corruption around the world: Evidence from a structural model. Journal of Comparative Economics, 35(3), 443-466.

Jöreskog, K. G. (1973). A general method for estimating a linear structural equation system. In A. S. Goldberg \& O. D. Duncan (Eds.), Structural equation models in the social sciences (pp. 85-112). New York: Academic Press.

Jöreskog, K. G. (2000). Latent variable scores and their uses. Retrieved from http://www.ssicentral.com/lisrel/techdocs/ Ivscores.pdf

Jöreskog, K. G., \& Goldberger, A. S. (1975). Estimation of a model with multiple indicators and multiple causes of a single latent variable. Journal of the American Statistical Association, 70, 631-639.

Kollo, P. (2012). Measuring ethnicity: The appropriate diversity index (IAI Discussion Papers No. 221). Göttingen: Ibero America Institute for Economic Research.

25 The maximum likelihood estimator with missing values ( $\mathrm{mlmv}$ ) is implemented into STATA's sem command in order to account for the missing values in the observable data (Jöreskog, 1973). Since the maximization of the log likelihood does not depend on the complete information of individuals, the estimator also considers all partially complete data in the estimation process. This procedure is similar to multiple imputation and provides unbiased estimates (Baraldis \& Enders, 2010).

${ }^{26}$ The linear prediction is specified as well and gives similar results with a rank correlation of larger than 85 percent. 
OECD. (2012). Transition economy and OECD membership. Retrieved from http://www.oecd.org/general/listofoecdmembercountries-ratificationoftheconvention-ontheoecd.htm

UNCTAD. (2012). United Nations Conference on Trade and Development Statistics. Retrieved from http://unctadstat. unctad.org/ReportFolders/reportFolders.aspx

UNODC. (2008). Surveys on crime trends and operations of criminal justice systems (UN-CTS). Vienna: United Nations Office on Drugs and Crime.

UNODC. (2012). Global report on trafficking in persons. Vienna: United Nations Office on Drugs and Crime.

World Bank. (2012). World development indicators. Washington, DC: World Bank. 